\title{
Eels, beavers and horses: Human niche construction in the European Late Upper Palaeolithic
}

By ANTONY G. BROWN, LAURA S. BASELL and REBECCA FARBSTEIN

\begin{abstract}
This paper examines interactions between co-occupants of riverine niches in North West Europe during the Late Upper Palaeolithic using both ecological and archaeological data. It is argued that consideration of both the Lateglacial record and autecology of eel, beaver and horse supports a reinterpretation of some famous but enigmatic panels of Magdalenian mobiliary art as representations of eel fishing, along with horse and beaver exploitation in disturbed riverine habitats. It is further suggested that this constitutes a humanly coconstructed niche in ecological, nutritional and symbolic terms, which was also particularly advantageous for human well-being and social development in this time and place.
\end{abstract}

Keywords: niche construction theory, Magdalenian, nutrition, mobiliary art, sedentism 


\section{Introduction}

Anatomically modern humans can be viewed as both occupants of a wide variety of Late Pleistocene ecological niches, and also modifiers of those niches (Laland and O'Brien 2010). This paper examines the interaction between Magdalenian (17,000-12,000 BP) co-occupants of the riverine niches in parts of North West Europe using both ecological and archaeological data. We go beyond a passive interaction between Late Upper Palaeolithic hominins and ecology to consider the creation and recognition of active and reciprocal ecological modifications as an application of niche construction theory (NCT; Odling-Smee et al. 2013). The functional context for this analysis is human survival and health, but the implications are behavioural and even cognitive. In this paper we first present key aspects of the ecology ( $c f$. autecology) of the key non-human species in this niche before relating them to human behaviour as reflected by mobiliary art.

A recent analysis of the distribution of Lower Palaeolithic super-sites in southern England and northern France by Brown et al. (2013) has highlighted the location-specific importance of fat and carbohydrate in balancing protein intake, and the importance of critical nutrients such as vitamins C, D, E and folate. The typical location of super-sites in the most nutritionally diverse locations in the interglacial landscapes of this region, (namely the lowest freshwater reaches on braided floodplains) strongly suggested that sources of fats, carbohydrate and critical nutrients may have been utilised from sources other than, or in addition to, large herbivores. It was also noted that humans co-inhabited this niche with a distinctive combination of flora and fauna including: aquatic plants, beaver and eel, as well as other fish and waterfowl. This zone also attracted the herbivores that butchery evidence suggests were the main target prey, particularly horse and deer.

However, for the Lower Palaeolithic, apart from tool type, palaeoecological data, and site distribution - all of which can have multiple drivers, there is little or no other behavioural information and as yet limited isotopic data (Bocherens, 2015). Data from analysis of dental calculus for microfossils (pollen, chemical compounds, starch, phytoliths, micro-charcoal and diatoms) is generating a wealth of fascinating information (SalazarGarcía et al. 2013; Hardy \& Buckley 2013; Buckley at al. 2014; Powers et al. 2015; Hardy et al. 2015; Hardy et al. 2016; Radini et al. in press). However, how such data, particularly 
phytoliths, relates to overall diet over the lifetime is still being established and is complicated by factors such as, differential preservation (Hardy et al. 2015; Power et al. 2015), difficulties of identification related to mastication damage (Shillito 2011), and the fact that these environmental signatures can become incorporated through breathing, eating, oral hygiene activities and raw material processing. The analysis of faecal biomarkers is an emergent field, but the results cannot be resolved to species level (Sistiaga et al. 2014). More behavioural data exist for the Late Upper Palaeolithic (Late Upper Palaeolithic (LUP), c. 15-10 ka BP) where additional data sources include portable and fixed art, a wider range of perishable artefacts and human isotopic data as well as reduced confounding factors as a result of higher chronological resolution and less post-depositional disturbance.

Human settlement of North West Europe in the LUP over the area covered by the Magdalenian culture (Fig. 1) must be seen in climatic context with high spatial as well as temporal variation, with biomes varying from tundra to cool temperate forest. After the Lateglacial maximum (LGM) this variation includes the rapid melting of permafrost which had covered all the non-glaciated parts of the British Isles, Central and Northern-Central France and the Low Countries as well as the northern part of the European Plain eastwards. This had melted by the Termination 1a c. $16.6 \mathrm{ka} \mathrm{BP}$ (end of the Heinrich 1 event meltwater pulse) which was marked by rapid warming with July temperatures rising $2-5^{\circ} \mathrm{C}$ into the lateglacial Interstadial (Windermere or Bølling Interstadial, Lotter et al. 2012). July temperatures show a declining trend of c. $2^{\circ} \mathrm{C}$ during this Interstadial with increasing instability (i.e. cold oscillations) culminating in the late-glacial Stadial (Younger Dryas) before the rapid warming at the beginning of the Holocene at 11.7 ka BP (Walker et al. 2009). Recent work by the INTIMATE project utilising tephrachronology (Blockley et al., 2012) has allowed regional event stratigraphies to be identified which although broadly phase-locked to the Greeenland NGRIP record do show significant variations which were manifest by regional to local variations in vegetation cover (Walker et al. 2012). The lack of well-developed soils and high rates of climate change promoted moderate to high ecological disturbance regimes with a high prevalence of, what we would recognise today as, early successional stages. For example open shrublands and light or scrubby woodland dominated by pioneers, ruderals and light-demanding herbaceous species (Peyron et al. 2005). Many of these species, now found as Arctic or Alpine plants, are calcicoles suggesting soils were far less acidified than 
they became in the early Holocene (Rhind and Jones 2003). One of the best Lateglacial records for Central France, La Taphanel, shows rapid variations in major taxa such as pine, juniper, birch, grasses, mugworts (Artemisia) and other herbs (e.g. Chenopodiaceae, Helianthemum) reflecting rapid climate change from just after the Lateglacial maximum, through the Older Dryas, the Allerød-Bølling, the Younger Dryas and finally rapid warming into the Preboreal (Ponel et al. 1990). These biomes had high herbaceous productivity which attracted, and may have been partly maintained by large herbivores, small mammals, and birds, but are without an analogy today (Gill et al., 2012). Fire may also have played an important role in maintaining moderate to high disturbance regimes (Thonicke et al. 2005) and variations in lithology, geomorphology and geo-hydrological conditions created locally variable vegetation patterns as has been show for the Netherlands (Hoek 1997). Of particular importance here is the probably persistence of more climatically temperate refugia, so called cryptic refugia (Birks \& Willis 2008), in valley floors dominated by willows, birch, hornbeam and alder (Ponel \& Cooper 1990).

Although this paper concentrates on the Magdalenian, the broader focus is on the wider interpretation of Palaeolithic artefacts and the relationship between different 'actors' within an ecological niche rather than an exhaustive survey of Magdalenian art. It is also important to note that ecological conditions through abrupt environmental transitions (AETs) were similar in other Interstadials in the MIS 3 such as IS 7 - IS 5 (van Andel \& Davies 2003; Davies et al. 2014). Two of the first migrants into this region during de-periglaciation were the European eel (Anguilla anguilla) from the west (Atlantic) and the European beaver (Castor fiber) from the east and south, with wild horse (Equus) probably surviving the LGM throughout most of Central to Northern Continental Europe (Bignon et al. 2005). By the Magdalenian (c. 17-12 ka BP) these three species were common throughout North West Europe and formed part of the ecosystems that Magdelanian people occupied and interacted with. 


\section{Eel, beaver and horse ecology}

There are aspects of the species specific ecology (autecology) of eels, beavers and horses that are of particular archaeological significance. Eels are ecologically and evolutionarily unusual fish which humans have always struggled to understand - Aristotle for example suggested that generated spontaneously from mud as he could find no larvae (Tsukamoto \& Kuroki 2014). from instantaneous. Although there are some 800 species of eel alive today, only the European freshwater eel (Anguilla Anguilla L. 1758) is commonly found in northwest European freshwaters. Anguilla anguilla is the only catadromous fish common in Europe descending rivers to the Sargasso Sea to spawn (Schmidt 1922) with the pelagic eggs and then larvae taking three years to drift with the North Atlantic Current back to the European shelf where they metamorphose into 'glass-eels' and then into elvers (civelles in France) before migrating upstream (Wheeler 1969). After living in rivers and lakes for 8-18 years they migrate downstream to begin their $6000 \mathrm{~km}$ journey to the Sargasso Sea where they spawn and die. The triggers for their spawning-migration as silver eels are not fully understood but appear to be influenced by declining day length (photoperiod), high rainfall and a complex effect of the lunar cycle (Bruijs and Durif 2009).

This life-cycle means that eel re-occupation of the region after the LGM would have been directly linked to the re-establishment of the Gulf Stream as the Polar Front retreated from $35^{\circ} \mathrm{N}$ to above $55^{\circ} \mathrm{N}$ in under 1000 years. This reoccupation would have occurred during the Lateglacial from glacial refugia in Iberia and using palaeoecological data (Kettles et al. (2008) show that eel was present in Central France by 19,000 BP although not into the British Isles until c. 11,000 BP (Table 1). Although some may die during their period in rivers and lakes most will die in the Sargasso Sea which makes their presence on LUP sites more likely to be due to human activity than natural processes. Eels can also spread rapidly from river to river and to lakes due to their semi-amphibian capabilities. As shown in this interglacial the European eel can occupy a wide range of habitats spanning the marinefreshwater ecotone, and this ecological plasticity (Vøllestad 1992) produces large variations in their stable isotopes values (Harrod et al. 2005). This also reflects eels' generalist diet being both carnivorous and a scavenger with the ability to sense blood through its keen sense of taste, one of its main prey being bloodworms although it eats fish, and larvae and indeed almost all aquatic fauna (Sinha and Jones 1975). Eels' semi-amphibian abilities to 
cross land and come out of water also allows them to feed on earthworms (Deelder 1985) and may be due to their overwhelming urge to migrate (Tesch 2003).

There are two other aspects of eel ecology which are particularly relevant to humans. Firstly eel is of high nutritional value being high in both protein $(66 \mathrm{~g}$ per $100 \mathrm{~g}$ ) and fat $(42 \mathrm{~g}$ per $100 \mathrm{~g})$ with high levels of polyunsaturated fat $(0.95 \mathrm{~g}$ per $100 \mathrm{~g})$. It is also high in several essential minor nutrients including potassium, phosphorous, iron, zinc and sodium, taurine and vitamins A, B6 and B12. Eels are also high in docosahexaenoic acid (DHA) which has recently been strongly linked to human brain development both directly and indirectly through mother's milk (Xiang et al. 2000; Brenna and Carlson 2014). The high nutritional value of eel was utilized in the Medieval and post-Medieval period in Europe when it became a major food source promoted by the Church and later a major source of nutrition for urban settlements (Bunting \& Little 2005). Eels were the fall-back food of settlers in North America who faced starvation in 1620 AD but traded for them with Native American peoples (Prosek 2011). Secondly it is the only common fish species in Europe that is ichthyohemotoxic; its blood is toxic to mammals, including humans. However the poison, which is a protein (Yoshida et al. 2008) that cramps muscles including the heart, is brokendown by any cooking, exposure to gastric juices, or naturally a few hours after the eel has died (Halstead 1988; Auerbach \& Halstead 2007). Experiments in the $19^{\text {th }}$ century showed that just a few drops of fresh eel blood could kill a medium-sized mammal such as a dog (Anon 1899; Sato 1917; Keffer \& Welsh 1936), then in the early $20^{\text {th }}$ century Charles Robert Richet tried to use it as a vaccine but found that it caused anaphylaxis, and more recently it has been trialled in both traditional Chinese and northern English folk medicine (Amin et al. 2003; Hatfield 2004). Although it may be difficult to prove its use on points of spears for hunting game it is a possibility and warrants further investigation.

Beavers (Castor fiber L. 1758) migrated back into North West Europe as part of the development of riverine woodlands and would have established themselves quickly in most river systems during this period (Table 1) from glacial refugia in Spain and SE France (Liarsou 2014). The basic biology and major role of beavers in modifying riverine habitats is described by Coles (2006) who also reviews their post LGM history from at least $15.5 \mathrm{ka}$ BP and recent redating of museum bones has confirmed that beaver survived through the Younger Dryas cold stage in South West England (Marr 2016). Recent work on beavers has 
shown that they are driven to dam running water through audible cues and in the absence of high levels of predation would come to a self-limiting density related to the density and gradient of streams (Meentemeyer \& Butler 1999; Westbrook et al. 2011). There are many ways in which beavers would have been of high value to hunter-gatherers from the high thermal value of their dense pelts, to their meat which is equivalent in energy to a roe deer (Coles 2006). There is also ethnographic evidence of their castor sacs being used as they contain a substance with similar medicinal properties similar to aspirin (Kitchener 2001). Other ethnographic examples exist of hunter-gatherers using their hafted teeth and mandible as a tools (Osgood 1940). One of their most valuable features may have been their tails which store fat and can be as much as $60 \%$ fat by weight during the winter (Kitchener 2001).

The wild 'caballine' horses of Lateglacial Europe which belonged to the species Equus caballus (Bignon et al. 2005), showed regional morphological variations which suggest they survived the LGM in mainland Europe rather than migrating in from the south or east (Bignon et al. 2005). Horse remains are found at most bone-rich Magdalenian sites indicating they were one of, if not the, prime prey species for humans (Nitecki \& Nitecki, 1987). These small sized horses were common in a variety of open-habitats and their dentition suggests they were adapted to grazing rather than browsing (Mihlbachler et al. 2011). The high land cover of sedges and graminoids would have promoted large herds (Bignon et al. 2005). The challenges presented by hunting free running herds are best addressed by ambush hunting, as demonstrated by ethnographic analogy (Stiner, 2002). While the earliest evidence for ambush hunting at 1.8 million years ago remains a matter of debate (Bunn \& Pickering 2010; Bunn \& Gurtov 2014; Pante et al. 2012), skeletal adaptations are consistent with modern human's ability to throw at high speed (Roach et al. 2013). Good evidence also exists that Lower Palaeolithic hominins hunted horses cooperatively (Stiner et al., 2009) as exemplified by the scapula of a horse punctured by a wooden spear found at Boxgrove GTP17 (Roberts \& Parfitt 1999) and the horses found in association with the famous Schöningen spears (Conard et al. 2015). Floodplains were an easy place to kill horses while they were drinking. Horses are not habituated to swimming and try to avoid it; if forced to swim, they are at their most vulnerable. Although the palaeoecological contexts of the examples given above support a floodplain ambush hunting 
scenario as early as the 500 ka BP, recent research has demonstrated that Schöningen was not a mass kill site and instead represents several separate episodes of hunting and butchery (Urban \& Bigga 2015; Balter 2014). Interestingly, new research on the site sediments has demonstrated that the spears and horse remains were not deposited on dry land, but in the lake under 1-2 metres of water (Urban \& Bigga 2015). After $250 \mathrm{ka} \mathrm{BP}$, it is more widely accepted that ambush hunting would have been possible (Stiner 2002) and certainly by the Magdalenian, horse and reindeer were dominant components of the diet (Kuntz \& Costamagno 2011), and seem to have been symbolically embedded in Magdalenian lifeways in a way that is not apparent for earlier periods (Langley 2013). An alternative to ambush hunting may be corralling, and even proto-domestication has been discussed for the Solutrean and Magdalenian (Lewis

By the early Magdalenian beaver, eel and horse were ubiquitous and probably numerous in Central France and common throughout the area by the middle to late Magdalenian (Table 1). Beavers are highly adaptable and this makes them in effect pioneer species (Liarsou 2014) and one which was almost certainly hunted (Petillon 2008). Recent evidence from the Caune de l'Arago shows that by the Lower Palaeolithic (MIS13), in southern France beaver was being systematically exploited for its skin and meat (Lebreton et. al. 2017). The attraction of horses to water and their vulnerability near it, and the effect of beavers on Lateglacial river systems, are just two of the ways these species interacted with each other and impacted the floodplain environment. Geomorphological research has shown that floodplains in this period were covered by secondary channels (Brown 1995; Pastre et al. 2003; Lespez et al. 2015) and beaver damming of these channels would have increased the year-round water availability - effectively creating many lakes or ponds (Coles 2006). This would have increased habitats available for fish (Häglund \& Sjöberg 1999), waterfowl and amphibians. The increase in fish, and other aquatic species would have increased eels in particular, and ponding would also have attracted grazing herbivores especially in drought periods. Such beaver-modified ecosystems would have been particularly attractive for humans who, if present in low numbers, could be regarded as a part of this ecological association. It is argued here that humans introduced another interaction between the species co-occupying this ecosystem through sophisticated food 
procurement strategies which would have, in turn, altered competitive conditions for plant growth as part of the constructed niche evolution (Allaby et al. 2015).

\section{Ethnographic evidence of eel fishing and ecological symbolism}

There are two principal methods of fishing for eels, both of which require only very basic equipment. The first method uses a long pole, called in English a 'poke pole' (Fig. 2). Generally, the long pole is over $2 \mathrm{~m}$ long and is used to flush out eels from behind rocks and in aquatic vegetation. Once flushed-out they can be caught by hand, a practice known by Maori peoples as 'bobbing, feeling and striking' or by the use of a basket, or eel spear. The pole can have a variety of ends, such as a hook or loop, or it can be a simple point. The other technique involves placing a severed horse head in shallow water to attract eels, which enter the cranial cavity through the orifices, attracted by the smell of rotting flesh. As reported in Smart (2003), the horse head is placed in water during the evening, and eels are squeezed out the following morning (Fig. 3). A single horse head can be used repeatedly until there is little flesh left (Smart 2003, pp 152-153). There is also evidence of ancient eel fishing techniques from non-European societies, particularly among the Maori peoples in New Zealand. A Maori myth proposes that eels could be attracted out of the water by small game, as depicted in a painting of a giant eel being caught at Tangahoe Lake, New Zealand painted by T. W. Downes in 1918. Maori eel hunters used both their hands and multi-tanged eel spears (matarau) and killing batons (patu tuna; Fig. 4) to kill eels, and they also constructed eel-weirs which are structurally very similar to natural beaver dams (Fig. 4). Although it is beyond the scope of this paper, baskets and weaving would have been helpful in trapping and transporting eels, and there is evidence of rope/cord from Lascaux (LerroyGourhan \& Allain 1998) and from earlier Gravettian sites from Europe (Adovasio et al. 1996; Soffer et al. 2000a, 2000b). This ecological zone would be the most resource-rich for basketry as withies (willow saplings), tall grasses and reeds (Hurcombe 2014) would have been readily available. There is archaeological support for ethnographic evidence of eel- 
catching with poles and killing batons. "Batons" or "Bâton de commandement" commonly found at Magdalenian and Cresswellian sites NW Europe would have been suited for killing fish, eel, and other small game, and harpoon-like antler projectile points might have been similarly useful as well as final Upper Palaeolithic 'Lyngby Axes' (Langley 2014).

Until recently many aspects of eel, beaver and horse ecology proved mysterious and/or remarkable to diverse cultures. The discovery of eels on land, but not on nights with a full moon (Bruijs \& Durif 2009), the movement of adult eels and fry through river mouths on full moons, their green glow (bioflourescence, Baker, 2013), and the relatively longlasting post-mortem convulsions which are similar to those of snakes (caused by muscle contractions) all engendered stories and myths. Even today, the unusual long-distance life cycle of the European eel is not fully understood (Baker 1978; Pfeiler 1986). Similarly, beavers are mythically significant to many cultures, as it is the only medium-sized mammal to produce complex structures, fell trees, and be semi-aquatic. Similarly ethnographic evidence from North America reveals a complex relationship between humans and beavers encoded in myth and metaphor (Dods 2003).

The symbolic importance of horse during the LUP is evidenced by the fact that they are by far the most dominant artistic subject, and especially in the Magdalenian (Rice \& Paterson 1996). Aspects of their ecology would have been noticeable to prehistoric huntergatherers, including their tight social grouping and mutual grooming behaviour. During the Magdalenian, there is evidence for the careful placement of horse teeth and bones in hearths within the caves of Labastide and Erberua, at the open site of Pincevent (Bahn and Vertut 1988; Lewis 2009) and the horse 'totem' cave at Ekain in the Basque Region (LeroiGourhan 1968). Associations between horse and eel persist today; in English the black line down the back of a horse is known as an "eel stripe" (Stachurska 1999) possibly because it was a common belief until the late $19^{\text {th }}$ century that a long black horse-hair thrown into running stream instantly became a live eel (Righton and Roberts 2014).

Archaeological evidence of Late Upper Palaeolithic eel, beaver and horse. 
Eel bones are relatively uncommon archaeological remains, and otoliths, which offer the best information about age, have yet to be reported at Palaeolithic sites (Kettle et al. 2008: 1320). Even in later prehistoric and into historic contexts, eel remains are very rare finds. For instance, there is written evidence of eel exploitation during the Medieval period, but the relative lack of their bones in the archaeological record suggests that their recovery is poor (Kettle et al. 2008) and also that preserving (e.g. smoking) and consumption softens bones so they are ingested or unlikely to be preserved. Indeed in several cultures, including Japanese, eel bones are themselves eaten as a delicacy. However, a few Magdalenian sites have yielded isolated eel remains. Trou du Frontal (Belgium) yielded two dentaries and a caudal vertebra (van Neer, Wouters, and Germonpre 2007: 8), and an eel "fishery" at Grotta della Serratura (Italy) suggested exploitation of immature yellow eel during the spring (Kettle et al. 2008).

Human exploitation of beavers is known from as early as the Lower Palaeolithic in Southern France (Lebreton et al. 2017) and beaver remains are evident throughout the Upper Palaeolithic in this region. The Aurignacian archaeozoological assemblage from Mladec Cave (Czech Republic) provides some of the earliest evidence of Upper Palaeolithic beaver exploitation (Svoboda 2001) along with bones from Kent's Cavern, UK (Campbell 1977; Currant \& Jacobi 2011). The important ornamental assemblage from the Mladec cave also includes nine perforated beaver teeth, at least one of which was excavated less than a metre from the famous human skull (Schwartz \& Tattersall 2006: Antl-Weiser 2006), suggesting symbolic interest in this species. Noteworthy LUP zooarchaeological assemblages from northwest Europe with significant quantities of beaver remains include the Magdalenian assemblage from Le Morin, France (Boudadi-Maligne et al. 2012), the Federmesser assemblage from Andernach, Germany (Stapert \& Street 1997: 179-180), Dog Hole cave at Cresswell, UK (Campbell 1977), King Arthur's Cave in the Wye Valley, UK (Currant \& Jacobi 2011).

Horse bones are ubiquitous throughout Palaeolithic archaeological horizons, and the species is commonly represented in art, from the Aurignacian through the Magdalenian (e.g. Graziosi 1960; Simões de Abreu \& Bednarik 2000; Pigaud 2002; Stevens et al. 2009). During the Lateglacial, horse would have made up a significant component of human diet (Bignon \& Turner 2003; Turner 2006). Rice \& Paterson (1996) calculated that $43.7 \%$ of Palaeolithic 
engravings are of horses. There is also evidence that the horses frequently portrayed in Magdalenian art were illustrative of real herds of animals (Hodgson 2003).

\section{Mobiliary Art}

At least four sites yielded mobiliary art that may offer evidence of human engagement with the beaver-eel-horse ecosystem and exploitation of these species. The first is the Magdalenian type-site of Abri de la Madeleine rock-shelter in the Vézère Valley in the Dordogne, first excavated in 1863-4 by Edward Lartet and Henry Christy and later by Denis Peyrony (in 1926) and dating largely to the late Magdalenian (c. 12,640-13,440 uncal. BP Boyle 1994; Gambier et al. 2000; Maier 2015). The Abbé Breuil interpreted one of the many zoomorphic engravings executed on a so-called "bâton de commandement," as a human representation, a snake or an eel, and two horse heads (Fig. 5). Marshack later described the same group of engravings more generally as a "complex composition of 'obscure significance" (Marshack 1972 p. 208), and there are some discrepancies between Marshack's (1972) and Breuil's transcriptions of the eyes on the anthropomorphic engraving. However, their transcriptions of the horse heads and snake- or eel-like animal are in accordance with one another. Other thematic elements on this engraving include a suggestion of water or a stream (which Marshack interpreted as vegetation), and a human figurine holding a long stick, spear, or pole.

We propose a revised interpretation of this depiction in which the snake-like animal may instead be interpreted as a European eel. This engraving includes a series of marks that seem to depict the confluent dorsal-anal and caudal fins (dorsal and ventral) near the tail end of an eel. Furthermore, the width to length ratio of the engraved animal is closer to that of an eel than to that of a grass-snake (Natrix natrix), which would be the most likely common snake to be associated with rivers and wetlands. However, we have a very incomplete record of snakes and other herpetofauna for the Lateglacial in this region, and snakes like most of the herpetofauna, are thermophiles, require a long enough period of summer warmth (over $1^{\circ}$ ) in order to incubate eggs (Gleed-Owen 1999). Three true snakes (Natrix natrix, Natrix maura and Vipera latasteri) are known from Magdalenian levels at Gorham's cave in Gibraltar (Blain et al. 2013) and it is assumed that Iberia was the nearest 
refugium for these species during the LGM. There is also evidence of snakes at two Magdalenian sites in the Pyrenees. At Bois du Cantet Cave, in the Hautes Pyrénées Natrix sp., Zamenis longissimus (Aesculapian snake) and Vipera aspis (European adder) were recorded, and at Malarode Cave, Pyrénées-Atlantiques remains of Natrix sp. (Bailon 1991; Bailon pers com. 2016). It therefore has to remain an open question as to whether snakes were present in sites further north such as Abri de la Madeleine, although it is likely by the end of the Magdalenian they would have migrated into this area assuming they had not survived in a local refugia (Stewart pers. comm.).

Although there is little definitive detail on the stick held by the anthropomorphic figure, it could depict either a poke pole for eel fishing or a harpoon. The downward orientation of the stick is strongly reminiscent of the way the eel poke pole is held and used. Marshack (1972) refers to two branches or leaves on the lower end of the pole, but in his drawing they are on opposing sides of the pole and quite uniform and symmetrical, so they might represent prongs on an eel spear, killing baton, or harpoon. This alternative interpretation leads, in turn, to a revised narrative for the whole engraving; it may depict humans exploiting eels using both a tool similar to a poke pole and a horses' heads as a an eel trap. This implies that the engraving may not be just a random assemblage of representational elements but rather an intentional narrative of activities that held both practical and symbolic importance to Magdalenian culture.

From the same site there is also a "fish carved on reindeer antler" on display at the Musée de Saint-Germain-en-Laye, (see http://donsmaps.com/laugeriebasse.html). We argue here that it is possible that this is also a representation of an eel for two reasons. Firstly, although the artefact is incomplete, the length and shape of the carved fish is more typical of an eel than other freshwater fish (although it could be argued that this shape was mandated by the morphology of the antler). Even if the shape of the depicted species was dictated in part by the material support, the rib depicted at the top of the body is more reminiscent of the dorsal fin of an eel than a pike, which would be the most likely alternative fish species.

Another baton from La Madeleine, curated at the British Museum, preserves four schematic engravings previously interpreted as "fish" (Sieveking 1987: 21, Plates 28 and 29) 
alongside, and in one case, superimposed on, an engraving of a horse. Several of these engravings are sufficiently abstract that they might be equally interpreted as schematic depictions of eels, and the hatched marks are particularly reminiscent of the scales and markings on eels. A similar "ladder" motif found on another baton from La Madeleine (Sieveking 1987: 20-21, Plates 26-27) was interpreted in the Reliquiae Aquitanicae (1875) as a schematised fish. However, the elongated shape of this motif and the suggestion of a dorsal fin again introduces the possibility that this motif represents an eel. The horse muzzle overlaps the eel/fish motif, spatially reinforcing the association between these two species; to modern viewers, the eel might appear to be moving into or out of the horse's head, similar to its expected behaviour while being trapped in a horse-head. There are also bevelled spear points from La Madeleine along with several harpoons and leisters from the site attesting to the importance of fishing to the site's occupants.

At Grotte de Montgaudier, Charante, Central France, a reindeer antler baton de commandement, found in 1886, was incised with depictions of two eels (whose fins are discernable), two feels, a fish, and vegetation and/or water (Fig. 6). It was first described 1887 by Albert de Nadaillac who clearly recognised the eels and regarded the site as late Magdalenian. The engraved baton was accompanied by pieces of ivory decorated with engravings and a pierced bone which was decorated with a frieze of three horses as well as perforated reindeer antlers decorated with two heads of goats (Airvaux 2002). It is relevant here that this site is only just above river level with the lower areas liable to flooding today.

An engraved bone from El Pendo, northwest Spain depicts a "horse and a serpent associated with a set of linear marks" (Marshack 1972, p211). Pozzi (2004) has noted that the representations on harpoons rarely represent terrestrial animals, so this example is unusual. By contrast the representation of fish on Magdalenian harpoons is frequent, although many are stylised and schematic (Pozzi 2004). Again the shape of the serpent is far more like an eel and it does not display the markings and forked tongue seen on representations that are almost definitely snakes such as the engraved bone from Grotte de Lorthet in the foothills of the Pyrenees (Breuil and Saint-Périer 1927; Marshack 1972, p. 223). The linear marks are curved and could represent water by analogue with depictions such as the line angles on the horse, bison and fish engraving on the eagle bone from La Vache (Ariègè) as interpreted by Marshack (1972, p. 275). 
An enigmatic representation from the Grotte du Mas d'Azil, Ariègè, depicts a horse's head with a thin irregular line emanating from its mouth (Fig. 7). This has generally been interpreted as grass or some form of foliage (Tyldesley \& Bahn 1983). Although possible, this seems rather prosaic and it is argued here that an equally plausible interpretation is that this also represents horse-head eel fishing. This is further supported by the presence of a possible "spear thrower" from the site with an unusual form (Garrod 1955). The spearthrower, illustrated in Piette (1907 pl. LI. No. 2), is $21 \mathrm{~cm}$ long and is thought to represent an eel with a small fish's tail against its head (Piette 1907; Garrod 1955). It is made on reindeer antler and its use as a spear thrower is considered dubious by Garrod for a variety of reasons; however, the representation of the eel remains significant, even if the purpose of the artefact remains enigmatic. An alternative interpretation of the artefact might be that this is instead a fishing device of some unknown function. Two other artefacts from Mas d'Azil reinforce the possible significance of horse-heads in the trapping and fishing of eels. A famous spear-thrower from the site depicts three horses heads in various stages of life and death (Mas D'Azil website 2012 - references). It has been interpreted as a young horse, an older horse, and a horse skull. The horse skull depiction is particularly relevant to this discussion of the importance of horse skulls in eel fishing. Another sculpture fragment from Grotto du Mas d'Azil has similarly been interpreted in the past as a horse head with the flesh removed. Overall, the graphic juxtaposition of images of life and death may be related to meaning associated with the use of the spear thrower in killing horses, but it should be noted that same life-death relationship is present in the use of a carcass to attract eels. An association between fish and horses and vegetation is also seen at Cueva los Casares where there are also images of possible anthropomorphic mustelids, such as otters, but which could also be reinterpreted as beavers (Fig. 8, see below for further discussion of beaver/otter representation)).

A strong association between fish and fertility is suggested at Bruniquel, Tarn-etGaronne (Sieveking 1987), where a broken baton, which was carved to the shape of a phallus, was decorated with fish and "angles probably representing water" (Marshack 1972, p. 330). A broken engraved bone from the same site is interpreted as a depiction of fish on one side and uncertain images, fish tails or trees on the other. An alternative interpretation 
is that these are fish or eel heads, and the uncertain images are eel spears, similar to those used by Maori, or a fish catcher (Marshack 1972, p. 200).

Several other sites have depictions that might be related. A rib bone from La Vache, in the French Pyrenees, was engraved with a horse head, which Marshack (1972: 225) interpreted as a stallion, followed by a mare; the two figures are separated by a symbolic branch. However, Marshack (1972) does not discuss the curved line emanating from the stallion's mouth which might be a schematic interpretation of an eel. Mobiliary art from other sites associates horses or horse's heads with rivers and fish. For instance, an engraving on stone from Trois Frères (Ariègè) features a small horse's head engraved over a fish (Marshack 1972, p. 244). Similarly, an engraving on a baton from Abri Mège, Teyjat, depicts a horse and deer head surrounded by three serpentine shapes (Marshack 1972, p. 260). At least one of the shapes has a pectoral fin while another has a clear lateral-line, suggesting that they are probably depictions of eels rather than snakes. At Grotte de Raymonden, Chancelade (Dordogne), a stone baton was engraved with a horse's head, fish, harpoon, and a possible bud or flower (Breuil 1937; Marshack 1972; Tyldesley \& Bahn 1983).

While evidence for the use of beaver pelts exists from at least the Middle Palaeolithic, (Fiore et al. 2004), there are only a few possible depictions of beavers in Magdalenian art. One of them comes from Abri de la Madeleine regarded by the Musée LesEyzies-de-Tayac as anthropomorph entitled " The sorcerer of La Madeleine" (Fig. 9). The other, which is an= very well known engraved image of two women-otter figures from the Middle Magdalenian levels at Isturitz (on display at the Musée Nationale de Préhistoire Les Eyzies de Tayac, Isturitz website references), Both images have traditionally been regarded as human-otters, and, in the La Madeleine case, an otter-like human/shamanistic being (Cooper 2001). However, this figure (Fig. 9) would appear to have a wide/fat tail and the 
other has a similar body shape and either no tail or possibly a fat tail rendered as feet. In these regards, both images are more likely to be beavers than otters, in which case, a symbolic link is suggested between the human form (and/or human behaviour) and beavers. The presence of beaver in the region during the Magdalenian is not in doubt (see Table 1), however, there is only find of fossil otter (Lutra lutra) from the Lateglacial in France and that comes from the Alps (Chaix \& Olive 1984) although finds are known from Germany and Poland (Knul pres. Comm.). Although it might be argued that otter would likely be underrepresented in caves and not being a human food resource (like most carnivores) there is no fossil data at present to question the view of Sommer \& Beneck (2004) that the European population of otter was restricted to a single glacial refuge and did not expand westwards into France until the Holocene. Other purported otter representations might be similarly reconsidered as beavers. For instance, an engraving from Laugerie Basse, Dordogne, repeatedly interpreted as an otter, is located adjacent to one fish engraving and overlapping another (MacCurdy 1924: 37, Guthrie 2006: 224). Like the other enigmatic zoomorphs discussed above, the purported "otter" is easily re-interpretable as a beaver.

\section{Niche Construction Theory and Lateglacial Human-Environment Interactions}

Niche construction theory (NCT) provides a potentially valuable framework for analysing the bi-directional interactions of humans with environments in the past which explicitly considers human behaviour, abiotic factors and ecological feedbacks within an evolutionary context (Smith 2007; Lewontin 2000; Odling-Smee et al. 2013; Allaby et al. 2015). Niche construction refers to the "modification of both biotic and abiotic components in environments via trophic interactions and the informed (i.e., based on genetic or acquired information) physical work of organisms" (Odling-Smee et al. 2013, p. 5). Of importance here is that this includes both actions by humans and also by other biotic components of the ecosystem. It is evolutionary in that it can increase carrying capacities, facilitate co- 
operative behaviour and lead to ecological inheritance with can include acquired social learning. This includes an element of selective pressure provided by a diet that would enhance brain development in infants and facilitate cognition, rapid learning and visual acuity (Cheetham et al. 2006; Agostini 2008). NCT goes beyond the extended phenotype approach (sensu Dawkins 1982) in considering such behaviour as more than adaptations, including by-products such as artifacts that include signs, signals or new behaviours which may or may not be "profitable" (Madden et al. 2012). In both evolutionary and archaeological terms NCT is important because it can; (a) influence the strength and selection acting on all participants (Odling-Smee et al. 2003), (b) increase the abundance of individuals by increasing fecundity and/or extending longevity and (c) encompass ecological spill-overs which are modifications to other species niches creating multiple co-evolutionary events. NCT also implicitly recognises ecological change through the occurrence of new assemblages creating potentially novel trophic interactions as must have been common under the rapidly changing climates and biogeographical biotic distributions during periods of rapid climate change such as the Late Upper Palaeolithic (Dawson et al. 2011; Birks and Birks, 2008). Thus particular associations brought into being by climatic change can interact to produce locationally-specific nutritional advantages for human populations, in this case along river-corridors. Of particular significance for this paper is the commonly cited example in the NCT literature of the beaver's dam which alters the environment of many populations and even the abiotic environment (Naiman et al. 1988; Odling-Smee et al. 2003). We can also differentiate niche construction (as with the beaver dams), opportunistic niche recognition via inherited environmental knowledge and niche maintenance through repeated use involving social memory.

\section{Interaction, Niche Construction and Discussion}

The re-interpretation of some panels of mobiliary art as possible depictions of interactions between eels (and in some cases fish), horses, and in a few cases beavers highlights the interactions between these species and Magdalenian hunter-gatherer-fishers. The similarity between fish or eel killing batons, bâton de commandement and bâton perforé should be explored more although they have been interpreted in a bewildering number of ways (Bahn \& Vertut 1988). It is also during the Magdalenian that harpoon technology becomes 
widespread (Julian 1982). It is not clear what the prey species were, but a link with fishing is most commonly made (Julien 1982, 1995; Román et al. 2012) although this is difficult to prove due to the lack of detailed studies of ichthyofauna.

In the riverine environments of mainland North West Europe along with the niche constructing activities of beavers we can add the involvement of Magdalenian peoples through butchery by rivers (attracting eels), and the hunting/trapping of eels and beavers (Fig. 10). This niche co-constructed by humans and beavers would have produced ecological spill-over effects of increases in waterfowl and fleshy tubors, such as reed-maces (Typha $\mathrm{sp}$.$) . In this context it is interesting to note that the highest proportion of all birds$ represented in art are water-birds such as swans, geese, ducks and heron (Bahn \& Vertut, 1988). This niche can also be seen in relation to evolving views on Magdalenian diet and nutrition as counterbalancing potentially excess protein in the Magdalenian diet (Speth, 1991). Whilst the Magdalenian in North West Europe has commonly been viewed as the 'reindeer-horse hunters' with regional variations (Ávarez-Fernández 2011) this is biased by the data which are largely artefacts, animal bones and a limited amount of isotopic data. Recent studies using different datasets such as dental calculus have argued for a much broader dietary base including significant plant consumption including underground storage organs (Power et al. 2015). This study also recovered a sponge spicule from dental calculus suggesting some plant or animal input from a freshwater habitat.

This can be seen as part of the co-evolution of plant-human relationships (Allaby et al. 2015) and which we argue here includes co-constructed riverine niches. These niches would also have been relatively stable in the face of climatic instability during this period (Bignon et al. 2005) and may have provided an expanded season of both protein and carbohydrate/fat. Any linkage between the exploitation of individual resources inevitably raises the question of seasonality. It has been argued that in the Magdalenian in France reindeer was hunted in the autumn/winter and horse in the spring/summer (Fontana, 2000). There is direct evidence of reindeer hunting in autumn from Verberie in Northern France (Enloe 2006). If so a link between the exploitation of horse and eel would suggest a spring to summer window, however, both eel and beaver are potentially available yearround. Beavers don't hibernate but store enough wood underwater to last the winter, which they can access even if the pond or river is frozen over and snow cover has made terrestrial 
plants inaccessible, and ethnographic records from North America indicate that beaver tail fat provided an important late winter fat component for human diet (Coles 2006). Winter availability also applies to several plant resources such as the rhizomes of reed-maces and the leaves of plants such as watercress (Rorippa nasturtum aquatic) which are high in valuable nutrients, particularly vitamin C. Although it is difficult to be precise about the targeted species, the noted rise of harpoons as an artefact type during this period reinforces the centrality of riverine environments (Julien 1982, 1995; Román \& Villaverde 2012). This accords well with Boyle's (2010) argument in favour of true specialisation during the Magdelenian and Solutrean, and it is possible to see how this adaptation could fit into arguments regarding the expansion of the Magdalenian to Northwest Europe (Miller 2012).

It is proposed here these relationships, between eel, beaver, horse and Magdalenian peoples, constitute a humanly constructed niche in both ecological and symbolic terms, which was also advantageous for human well-being and social development in at least two ways. Firstly it allows year-round occupation which has reproductive, social and cultural consequences (Shennan 2001; Zubrow 2010). Secondly the diet, and in particular the high consumption of eels, eggs and fish would be unusually high in long-chain polyunsaturate acids (LCPs, including omega-3 and omega-6) and docosahexaenoic acid (DHA). These nutrients are all known to promote eye and brain development in babies and social learning (Xiang et al. 2000; Brenna \& Carlson 2014; Birch et al. 2007; Kuratko et al. 2013). In terms of culture and to paraphrase Lévi-Strauss (1964), food and cooking is a language - and an essential part of group identity and culture. Both the sedentism and the nutritional advantages are part of the ecological feedbacks and selective pressure within an evolutionary context that underlie niche construction theory (Smith 2007; Lewontin 2000; Odling-Smee et al. 2013; Allaby et al., 2015) and simultaneously can be seen as part of the way human agency was created and transformed through inhabitation of complex material conditions (Barrett 2001) We suggest here that the representation of the affluence and development of such a society is embodied in the symbolism of the artistic representations discussed here.

\section{Conclusions}


It is argued here from a combination of ecology, palaeoecological evidence and the reinterpretation of several pieces of mobiliary art that Magdalenian hunter-gatherers had honed the skill set and technologies necessary to undertake eel-fishing using poke poles, nets, or baskets, and horse heads used as traps. These innovations which are part of the 'broad spectrum evolution' could have arisen when eels were attracted to horse butchery sites in shallow channels and on river banks, and the roots of these practices might extend even earlier in the Palaeolithic. This can also be seen as part of a larger socio-ecological interaction between humans and beavers, with horses and eels (as beaver dams are readymade eel traps and ideal for horse-head eels traps) which we argue formed part of a particularly valuable and probably symbolically loaded humanly constructed niche. The similarity between hedge-type fish traps now known to date from at least the early Mesolithic in North West Europe (Zvelebil 2008; Smart 2003; Zhilin 2014) suggests this niche construction could have been an integral part of associative innovation which extended north during the Magdalenian. Both the act of depicting eels, horses and beavers as elements on mobiliary art at sites with other elements of ritual significance, and the biology of these three animals (which have engendered myths until the present day), suggests that they were part of a animistic association which represented important elements of the Magdalenian peoples view of both themselves and other occupants of this ecological niche. This also implies that key panels of Magdalenian mobiliary art could be seen as representing ecological assemblages and a constructed niche rather than isolated biological, resource or symbolic elements. Seen as such this is part of the deeper time-depth of co-evolutionary process with selective pressure that lead eventually to domestication of key species such as the horse (Allaby et al., 2015). This behaviour is also part of an evolving socio-ecological cognition that some have argued forms part of modern human behaviour.

However, the existence of this ecological association earlier in the Pleistocene, but relative lack of artistic representation, cautions against such an interpretation. Indeed whilst the primary focus for this paper has been on the Magdalenian, there is intriguing evidence that the association of hominins in this particular niche may have much deeper roots. For example the site of Cueva Millán dating to 37,600 BP yielded 6 species of fish including trout (Salmo truta farios, $\mathrm{N}=198$ ), Iberian nase (Chondrostoma polylepsis, $\mathrm{N}=52$ ) and eel (Anguilla Anguilla $\mathrm{N}=29$ ) in association with human activity (Izquierdo 1992; Boyle 2010). Even older 
is the remarkable 2012 discovery of the Eemian site of Waziers, France (minimum U/Th age of 103+3.5/-3.4 ka, Hérisson et al. 2015) where wood shows clear marks of beaver activity and a cut mark on one of the beaver bones (Castor fiber) (Hérisson pers comm 2015). Although analysis is still underway, a range of other interglacial fauna were also present including horse, roe and red deer (Hérisson pers comm 2015). Whilst we can never put ourselves in the place of these Palaeolithic peoples, and the use of ethnographic analogy such as Maori or even historical eel fishing, should be used with care (Lane 2014), a holistic approach to understanding their artefactual remains and landscapes surely places some constraints on the plethora of possibilities and can only improve our interpretations of artefactual evidence. Re-interpreting some key Palaeolithic art objects also highlights the importance of studying Palaeolithic art in its broader ecological and archaeological context, rather than continuing to focus on the iconographic features and interpret them in isolation.

\section{Acknowledgments}

Thanks to John Stewart, Chris Gleed-Owen, Mark Roberts, Katheryn Boyle, William Davies, John Stewart, Monika Knul, Mike Lobb, Kevin Walsh, Mark Gardiner, Finbar McCormick, Exra Zubrow and Des Tatana Kahotea for helpful discussions on this topic which improved the paper. Thanks also to Don Hitchcock for assistance with photographic materials.

\section{References}

Aaris-Sorensen, K. 2009. Fossils and Strata, diversity and dynamics of the mammalian fauna in Denmark throughout the last glacial interglacial cycle 115-0 BP. Fossils and Strata 57, 159.

Adavasio, J.M., Soffer, O., \& Klima, B., 1996. Upper Palaeolithic Fibre Technology: interlaced woven finds from Pavlov I, Czech Republic, c. 26,000 years ago. Antiquity 70:526-34.

Agostoni, C. 2008. Role of long-chain polyunsaturated fatty acids in the first year of life. $J$ Pediatr Gastroenterol Nutr. 47 Suppl 2:S41-4

Allaby, R. G., Kistler, L., Gutaker, R.M., Ware, R., Kitchen, J. L., Smith, O. and Clarke, A.C. 2015. Archaeogenomic insights into the adaptation of plants to the human environment: pushing plant-hominin co-evolution back to the Pliocene. Journal of Human Evolution 79, 150-157.

Alpert, B.O. 2013 The Meaning of the Dots on the Horses of Pech Merle. Arts 2, 476-490.

Airvaux, J. 2002. L'art préhistorique du Poitou-Charentes. Editions La Maison des Roches, Paris.

Amnin, C., Yingfu, M.,Yuan, G. \& Zhemin, G. 2003. Encyclopedic Reference of Traditional Chinese Medicine. Springer-Verlag, Heidelberg. 
Anon, 1899. Poison in the blood of the eel. New York Times $9^{\text {th }}$ April 1899.

Antl-Weiser, W. 2006. Szombathy's excavations in the Mladec cave and the first presentations of the results, in M. Teschler-Nicola (ed.), Early Modern Humans at the Moravian Gate: Mladec Caves and their Remains, 1-16. Vienna/New York, Springer.

Auerbach, P.S. \& Halstead, B.W. 2007. Hazardous aquatic life. In: Auerbach, P. S. and E. C. Geehr, [Eds.], Management of Wilderness and Environmental Emergencies. 2nd ed. C.V. Mosby Co., St. Louis. pp. 933-1028.

Ávarez-Fernández, E. 2011. Humans and marine resources interactions reappraised: archaeofauna remains during the Late Pleistocene and Holocene in Cantabrian Spain. Journal of Anthropological Archaeology 30, 327-343.

Bahn, P. \& Vertut, J. 1988. Images of the Ice Age. Windward: Leicester/Facts on File, New York.

Bailon, S. 1991. Amphibiens et Reptiles du Pliocène et du Quaternaire de France et d'Espagne: mise en place et évolution des faunes. Unpublished M.S. thèse, Université Paris 7, France.

Baker, M. 2013 First fluorescent protein identified in a vertebrate. Scientific American 13190

Baker, R. R. 1978. The evolutionary ecology of animal migration. Homes and Meier, New York.

Balter, M. 2014. The Killing Ground. Science Magazine 344, 1080 - 1083.

Barrett, J. 2001. Agency, the duality of structure, and the problem of the archaeological record. In In Hodder, I (ed.) Archaeological Theory Today (1st edition) Cambridge, Cambridge University Press, 141-164.

Barton et al. 1991

Bignon, O \& Turner, E. 2003. Horse hunting and the utilization of horse carcasses during the Magdalenian in Europe. British Archaeological Reports International Series S65, Oxford.

Bignon, O., Baylac, M., Vigne, J-D., Eisenmann, V. 2005. Geomteric morphometrics and the population diversity of Lateglacial horses in Western Europe (Equus caballus acrcelini): phylogeographic and anthropological implications. Journal of Archaeological Science 32, 375-391.

Birch, E.E., Garfield, S., Castaneda, Y., Hughbanks-Wheaton, D., Uauy, R., Hoffman, D. 2007. Visual acuity and cognitive outcomes at 4 years of age in a double-blind, randomized trial of long-chain polyunsaturated fatty acid-supplemented infant formula. Early Human Development 83,279-284. 
Birks H. J. B. \& Birks H. H. 2008. Biological responses to rapid climate change at the Younger Dryas-Holocene transition - succession, diversity, turnover, and rates of change. Holocene 18, 19-30.

Birks, H.J.B. \& Willis, K. 2008. Alpines, trees, and refugia in Europe. Plant Ecology and Diversity 1, 147-160.

Blain, H-A, Gleed-owen, C., Carriónd, J. S., Jennings, R., Finlayson, G. \& Giles-Pacheco, F. 2013. Climatic conditions for the last Neanderthals: Herpetofaunal record of Gorham's Cave, Gibraltar. Journal of Human Evolution 64, 289-299.

Bocherens, H. 2015 Isotopic tracking of large carnivore palaeoecology in the mammoth steppe. Quaternary Science Reviews 117, 42-71.

Blockley, S., Bourne, A., Brauer, A., Davies, S.M., Hardiman, M., Harding, P.R., Lane, C.S., MacLeod, A., Matthews, I.P., Pyne-O'Donnell, S.D.F., Rasmussen, S.O., Wulf, S. \& Zanchetta, G. 2012. Tephrochronology and the extended intimate (integration of ice-core, marine and terrestrial records) event stratigraphy 8-128 ka b2k. Quaternary Science Reviews 106, 88-100.

Bocquet, A., 1969. L'Isère préhistorique et protohistorique. Gallia Préhistoire, 12 (1), 121-400.

Brenna, J.T. \& Carlson, S.E. 2014. Docosahexaenoic acid and human brain development: Evidence that a dietary supply is needed for optimum development. Journal of Human Evolution 77, 99-106.

Brochier, J.E. \& Livaxhe, M. 1978. Le niveau C de l'abri n¹ de Chinchon à Saumanes de Vaucluse: analyse des correspondances et ses conséquences quant à l'origine des complexes du Le niveau $C$ de l'abri n 1 de Chinchon à Saumanes de Vaucluse. Géologie Meditarréene 4, 359-369.

Brown, A.G. 1995. Lateglacial-Holocene sedimentation in lowland temperate environments: floodplain metamorphosis and multiple channel systems. Palaeoclimate Research/ Paläoklimforschung 14, 1-15.

Brown, A.G., Basell, L.S., Robinson, S. \& Burge, G.C. 2013. Site Distribution at the Edge of the Palaeolithic World: A Nutritional Niche Approach. PLoS ONE 8(12), e81476, 1-14.

Breuil, H. 1937. Les Subdivisions du Palèolithique Supérieur et leur Signification. 2nd Edition.

Breuil, H. \& Saint-Périer, R. 1927. Les poisons et les reptiles dans l'art quaternaire. Archives de l'Institut de Paléontologie Humaine. Mémoire 2. Paris.

Boudadi-Maligne, M., Mallye, J.-B., Langlais, M. \& Barshay-Szmidt, C. 2012. Magdalenian dog remains from Le Morin rock-shelter (Gironde, France). Socio-economic implications of a zootechnical innovation. Paleo 23: 39-54.

Boyle, K.V. 1994. La Madeleine (Tursac, Dordogne). Une étude paléoéconomique du 
Paléolithique supérieur. Paleo 6, 55-77.

Boyle, K.V. 2010. From laugerie basse to jolivet: The organization of final Magdalenian settlement in the vézère valley. World Archaeology 27, 477-491.

Bozinski, G. 1979. Stratigraphie du Paléolthique supéreur recent et du Paléolthique final dans le basin de Neuwied (vallée du Rhon moyen RFA). In de Sonnervilles-Brodes, D. (Ed.) Le Fins des Temps Glaciares en Europe. Colloques Internationaux du CNRS 271, 193-201.

Bosninski, G. 1983. Die Jägerische geshichte dew Rheinlandes - einsichen und lucken. Jahbruch des Romisch-Germanischen Zentralsmuseums Mainz 30, 81-112.

Bruijs, M.C.M. \& Durif, C.M.E. 2009. Siver eel migration and behaviour. In van den Thillart et al. (eds.) Spawning Migration of the European Eeel. Springer Science+Business Madia B.V. 65-95.

Buckley, S., Usa, D., Jakob, T., Radini, A. \& Hardy, K. Dental Calculus Reveals Unique Insights into Food Items, Cooking and Plant Processing in Prehistoric Central Sudan. PLoS ONE 9(7), e100808.

Bunting, S.W. \& Little, D. C. 2005. The emergence of urban aquaculture in Europe. In CostaPierce, B., Desbonnet, A and Slater, D. Urban Aquaculture. CAB International, 119-137.

Bunn, H.T. \& Pickering, T.R. 2010. Bovid mortality profiles in paleoecological context falsify hypotheses of endurance running-hunting and passive scavenging by early Pleistocene hominins. Quaternary Research 74, 395-404.

Bunn, H.T. \& Gurtov, A.N. 2014. Prey mortality profiles indicate that Early Pleistocene Homo at Olduvai was an ambush predator. Quaternary International 322-323. 44-53.

Burkitt, M.C. 1921. Prehistory: A Study of Early Cultures in Europe and the Mediterranean Basin. Cambridge University Press, Cambridge.

Campbell, J. B. 1977. The Upper Palaeolithic in Britain: A Study of man and Nature in the Late Ice Age. Clarendon Press, Oxford.

Chaix, L. \& Olive, C. 1984. Étude de la faune de l’Epipaléolithique à la Tène. Bulletin de la Société Préhistorique Française, 81, 337-341.

Cheatham, C.L., Colombo, J. \& Carlson, S.E. 2006. n-3 Fatty acids and cognitive and visual acuity development: methodologic and conceptual considerations1'2'3'4. Am J Clin Nutr 83 no. 6, S1458-1466S.

Clark, J.G.D. 1936. The Mesolithic Settlement of Northern Europe. Cambridge University Press, Cambridge.

Coles B. 2006. Beavers in Britain's Past. Oxford, Oxbow Books. 
Conard, N.J., Jordi Serangeli, J., Böhner, U., Starkovich, B.M., Miller, C.E., Urban, B. \& Van Kolfschoten, T. 2015. Excavations at Schöningen and paradigm shifts in human evolution. Journal of Human Evolution 89, 1-17.

Cooper, M. 2001. Exploring the Ice Age. Atheneum, London.

Cordy, J-M. 1991. Palaeoecology of the lateglacial and early postglaicial of Belgium and neighbouring area. In Barton, N.J., Roberts, A.J. \& Doe, D.A. (Eds.) The Late-glacial of North West Europe. Council for British Archaeology Research Report 77, 40-47.

Couloonges, L., 1963. Magdalénien et périgordien post-glaciaires: la grotte de La Borie del Rey ( Lotet-Garonne ). Gallia Préhistoire, 6 , 1-29.

Cravinho, S. and Desse-Berset, N. 2005. Les poissons du Bois-Ragot (Gouex, Vienne). In: Chollet, A. (Ed.) La grotte du Bois-Ragot à Gouex (Vienne): Magdalénien et Azilien: essais sur les homes et leurs environnements. Mémoire de la Societé pre' historique francaise 38, 355371.

Crégut-Bonnoure, E. 1992. La faune de Mammifères de Chinchon II (Saumane-de-Vaucluse, Vaucluse). Bulletin Archéologique de Provence 21, 9-13.

Currant, A.P. 1986. The Lateglacial mammal fauna of Gough's Cave, Cheddar, Somerset. Proceedings of the University of Bristol Spelaeological Society 17, 286-304.

Currant, A. P. \& R. Jacobi. 2011. The mammal faunas of the British Late Pleistocene. The Ancient Human Occupation of Britain (ed. N.M. Ashton, S.G. Lewis, and C.B. Stringer). 181222. Amsterdam : Elsevier.

Dachary, M., 2008. Le Magdalénien des Pyrénées occidentales. Universite de Nanterre

Davies, W., White, D., Lewis, M. \& Stringer, C. 2014. Evaluating the transitional mosaic: frameworks of change from Neanderthals to Homo sapiens in eastern Europe. Quaternary Science Reviews 118 211-242.

David, S., 1996. La fin du Paléolithique supérieur en Franche-Comté : environnement, cultures, chronologie. Gallia Préhistoire, 38 (1), 111-248.

Dawkins, R. 1982. The extended phenotype. Freeman Press, Oxford.

Dawson T.P., Jackson S.T., House J.I., Prentice I. C. \& Mace G.M. 2011. Beyond predictions: biodiversity conservation in a changing climate. Science 332, 53-58.

Deelder, C.L. 1985. Exposée synoptique des données sue languille, Anguilla Anguilla (Linnaeus 1758). Food and Agriculture Organisation (FAO) Synopsis Pêches 80 Revue 1, 71p.

Dods, R. 2003. Wondering The Wetland: archaeology through the lens of myth and metaphor in Northern Boreal Canada. Journal of Wetland Archaeology 3, 17-36. 
Duche, G. 1986-87. Premiere approche de la faune ichtyologique du Niveau 2B du Bois des Brousses. Aniane, Herault. Études Quaternaires Languedociennes, Cahier No. 5, pp. 14-20.

Enloe, J. G. 2006 Geological Processes and Site Structure: Assessing Integrity at a Late Paleolithic Open-Air Site in Northern France. Geoarchaeology: An International Journal 21, 523-540.

Fabre, M., 2010. Environnement et subsistance au Pléistocène supérieur dans l'est de la France et au Luxembourg : Étude ostéologique des gisements de la Baume de Gigny (Jura), Vergisson II (Saône-etLoire) et Oetrange (Luxembourg). Universite Aix-Marseille I Retrieved from http://www.theses.fr/2010AIX10039

Fiedorczukt, J., Bratlund, B., Kolstrup, E. and Schild, R., 2007. Late Magdalenian feminine flint plaquettes from Poland. Antiquity, 81 (311), 97-105.

Fiore, I., Gala, M. \& Tagliacozzo, A. 2004. Ecology and Subsistence Strategies in the Eastern Italian Alps during the Middle Palaeolithic. International Journal of Osteoarchaeology 14. $273-286$.

Fontana L. 2000. La chasse au renne au Paléolithique supérieur dans le Sud-ouest de la France : nouvelles hypothèses de travail, in : Paléo, n¹2, Décembre 2000, p.141 à 164 Fosse, P., 1999. La grande faune mammalienne : remarques préliminaires. L'habitat Magdalénien de La Grotte Bourrouilla À Arancou (Pyrénées Atlantiques). Gallia Préhistoire, Tome 41, 98-113.

Gambier, D., Valladas, H., Tisnerat-Laborde, N., Arnold, M., and Bresson, F. 2000. Accelerator mass spectrometry radiocarbon dating of human remains from the Upper Palaeolithic. Paléo 12, 201-212.

Garrod, D. 1955. Palaeolithic Spear Throwers. Proceedings of the Prehistoric Society 21, 2135.

Giacobini, G., 2006. Richesse et diversité du rituel funéraire au paléolithique supérieur. Diogène, Diogène (214), 24-46.

Gill, J.L., Williams, J.W., Jackson, S. T., Donnelly, J.P. \& Schellinger, G.C. 2012. Climatic and megaherbivory controls on late-glacial vegetation dynamics: a new, high-resolution, multiproxy record from Silver Lake, Ohio. Quaternary Science Reviews 34, 66-80.

Gleed-Owen, C.P. 1999. The palaeoclimatic and biostratigraphic significance of herpetofaunal remains in the British Quaternary. In Andrews, P. and Banham, P. (Eds.) Late Cenozoioc Environments and Hominid Evolution: A Tribute to Bill Bishop. Geological Society of London, 201-215.

Guthrie, R.D. 2006. The Nature of Paleolithic Art. Chicago. University of Chicago Press.

Graziosi, P. 1960. Paleolithic Art. New York, McGraw Hill 
Häglund, A. \& Sjöberg, G. 1999 Effects of beaver dams on the fish fauna of forest streams. Forest Ecology and Management 115, 259-266.

Halstead, B.W. 1988. Poisonous and venomous marine animals of the world. 2nd rev. ed. Princeton, NJ, Darwin Press, p.1168.

Hardy, S. \& Buckley, Huffman, M. 2013. Neanderthal self-medication in context. Antiquity, $87,873-878$.

Hardy, K. Radini, A. \& Buckley, S. 2015. Diet, medicines, raw materials or palaeoenvironments? A broad approach to materials extracted from Palaeolithic dental calculus. European Society for Human Evolution Conference, British Museum London, Podium Presentation: Session 11A, Sa (15:40)

Hardy, K., Radini, A. , Buckley, S. Sarig, R, Copeland, L. Gopher, A. \& Barkai, R. 2016. Dental calculus reveals potential respiratory irritants and ingestion of essential plant-based nutrients at Lower Palaeolithic Qesem Cave Israel Quaternary International 398, 129-135.

Harrod, L., Grey, J., McCarthy, T.K. \& Morrisey, M. 2005. Stable isotope analyses provide new insights into ecological plasticity in a mixohaline population of European eel. Oecologia $144,673-683$.

Hatfield, G. 2004. Encyclopedia of Folk Medicine: Old World and New World Traditions. ABCCLIO, Santa Barbara.

Hérisson, D., Locht, J.-L., Vallin, L., Deschodt, L., Antione, P., Auguste, P., Limondin-Lozouet, N., Lefèbvre, S., Hulin, G., Masson, B. \& Ghalen, B. 2015. Neandertals' Presence during the Eemian Interglacial in North-western Europe: a New Site at Waziers (NorthernFrance) European Society for Human Evolution Conference, British Museum London, Podium Presentation: Session 10B, Sa (14:50)

Hodgson, D. 2014. The Significance of the Pech Merle Spotted Horses. Arts 3, 207-212;

Hodgson, D. 2003. The Biological Foundations of Upper Palaeolithic Art: Stimulus. Percept and Representational Imperatives. Rock Art Research 20, 3-22.

Hoek, W.Z. 1997. Patterns of Lateglacial vegetation in The Netherlands. Eiszeitalter $u$. Gegenwart 47, 78-88.

Hollman, J.A. 1998. Pleistocene Amphibians and Reptiles in Britain and Europe. Oxford Monographs in Geology and Geophysics No. 388, Oxford University Press, Oxford.

Hurcomb, L. 2014. Perishable Material Culture in Prehistory: Investigating the Missing Majority. Routledge, London. 
Isturitz Websites. Musée d'Archeologie Nationale et Domaine, St-Germain-en-Laye. http://musee-archeologienationale.fr/ and http://donsmaps.com/isturitz.html and http://www.arretetonchar.fr/

Izquierdo, E.R. 1992. La ictiofauna musteriense de Cueva Millan (Burgos): consideraciones de indole biologica y cultural contrastadas con ictiocenosis paleoliticas Cantabriccas. Estudios Geologica 48, 79-83.

Jochim, M. 2012. Coping with the Younger Dryas in the heart of Europe, in M. Eren (ed.) Hunter-Gatherer behaviour: human responses during the Younger Dryas, 165-78. Walnut Creek (CA), Left Coast Press.

Julien, M. 1982. Les harpons Magdaléniens. Editions du Centre national de la recherche scientifique, Paris 288p.

Julien, M. 1995. Harpons Magdaléniens. In Averbouth, A., Bellier, C., Billambozet, A. (Eds.) Fiches Typologiques de L'industrie Osseus Préhistorique. Cahier VII: Élements Barbelés et Aparents. Centre d'Etudes et de Documentation Aicheoiogiques (CEDARC). Treignes, 83-99.

Keffer, W.J. \& Welsh, A.E. 1936. Hemolytic and toxic properties of certain serums. Mendel Bulletin 8, 76-80.

Kettle, A. J., Heinrich, D., Barrett, J. H. Benecke, N. \& Locker, A. 2008. Past distribution of European freshwater eel from archaeological and palaeontologist evidence. Quaternary Science Reviews 27, 4309-1334.

Kitchener, A. 2001. Beavers. Stowmarket, Whittet Books.

Knight, B. 2011. Pech Merle Horses Really Were Spotted, Scientists Say. Deutsche Welle, November, Available online: http://www.dw.de/pech-merle-horses-really-were-spottedscientistssay/a-15517588 (accessed 06 May 2015).

Kuntz, D. \& Costamagno, S. 2011. Relationship between reindeer and man in southwestern France during the Magdalenian. Quaternary International 238, 12-24.

Kuratko et al 2013 Kuratko, L.N., Cernkovitch Barertt, E., Nelson,E.R. \& Salem, N. 2013. The relationship of docosahexaenoic acid (DHA) with learning and behaviour in healthy chidren: $A$ review. Nutrients 5, 2777-2810.

Laland K.N., O'Brien M. J. 2010 Niche construction theory and archaeology. J Archaeol Method Theory 17: 303-322.

Lane, P. 2014. Hunter-gatherer-fishers, ethnoarchaeology and analogical reasoning. In V. Cummings, P. Jordan and M. Zvelebil (eds) Oxford Handbook of the Archaeology and Anthropology of Hunter-Gatherers. Oxford, Oxford University Press, 104-50.

Langley, M.C. 2013. A Newly Discovered Horse Engraving from La Madeleine (Dordogne), France. Proceedings of the Prehistoric Society 79, 377-381. 
Langley, M. 2014. Magdalenian antler projectile point design: Determining original form for uni- and bilaterally barbed points. Journal of Archaeological Science 44, 104-116.

Le Gall, O. 1999. Ichtyophagie et pe 'ches prehistoriques. Quelques donne' es de l'Europe occidentale. Ph.D. Thesis, L'Universite' Bordeaux I.

Lebreton, L., Moigne, A-M., Filoux, A., Perrenoud, C. 2017. A specific small game exploitation for Lower Paleolithic: The beaver (Castor fiber) exploitation at the Caune de I'Arago (Pyrénées-Orientales, France). Journal of Archaeological Science: Reports 11, 53-58.

Leroi-Gourhan, A. 1968. The Art of Prehistoric Man in Europe. Thames \& Hudson, London.

Leroi-Gourhan, A. \& Allain, J. 1998. Lascaux inconnu. Editions du CNRS, Paris.

Lespez, L., Viel, V. Rollet, A.J. \& Delahaye, D. 2015. The anthropogenic nature of present-day low energy rivers in western France and implications for current restoration projects. Geomorphology 251, 64-76.

Lévi-Strauss, C. 1964. The Raw and the Cooked. Plon, Paris.

Lewontin, R. C. 2000. The Triple Helix: Gene, Organisms and Environment. Harvard University Press, Cambridge (Massachusetts).

Lewis, B. 2009. Hunting in Britain from the Ice Age to the Present. The History Press.

Liarsou, A., 2014. Zones refuges glaciaires et processus de recolonisation tardiglaciaire et holocene du castor ( Castor fiber L .) en Europe : apercu synthetique des donnees archeozoologiques. HAL Archives-Ouvert, 1-24.

Lotterr, A.F., Heiri, O., Brooks, S., van Leeuwen, J.F.N., Eicher, U. \& Ammann, B. 2012. Rapid summer temperatuire change during Termination 1a: high resolution multi-proxy clkimate reconstructions from Gerzensee (Switzerland). Quaternary Science Reviews 36, 103-113.

Ludwig, A., Pruvost, M., Reissmann, M., Benecke, N., Brockmann, G.A., Castaños, P., Cieslak, M., Lippold, S., Llorente, L., Malaspinas, A.S. et al. 2009. Coat color variation at the beginning of horse domestication. Science 324, 485.

Lupo, K.D., \& Schmitt, D.N., 2002. Upper Palaeolithic Net-Hunting, Small Prey Exploitation, and Women's Work Effort: a view from the ethnographic and ethnoarchaeological record of the Congo Basin. Journal of Archaeological Method and Theory 9, 147-179.

MacCurdy, G.G. 1924. The field of Paleolithic art. American Anthropologist 26, 27-49.

Madden, J.R., Dingle, C., Isden, J., Sparfield, J., Goldizan, A.W. \& Endler, J.A. 2012. Male spotted bowerbirds propagate fruit for use in their sexual display. Current Biology 22, R264R265. 
Maier, A. 2015. The central European Magdalenian. Springer, Dordrecht.

Marr, M. 2016. Radiocarbon dating of European beaver (Castor fiber L. 1958) from Gough's Cave provides evidence of population persistence over the Younger Dyras in Britain. Proceedings of the University of Bristol Speleological Society 27, 105-108.

Marshack, A. 1972. The Roots of Civilisation: the Cognitive Beginnings of Man's First Art, Symbol and Notation. McGraw Hill, New York.

Mas D'Azil website 2012 - references: http://anetchaparisienne.blogspot.com.au/2012/09/en-passant-par-saint-germain-en-laye.html and http://donsmaps.com/masdazil.html

Meentemeyer, R.K., Butler, D.R., 1999. Hydrogeomorphic effects of beaver dams in Glacier National Park, Montana. Physical Geography 20, 436- 446.

Mihlbachler, M.C., Rivals F., Solounias N., Semprebon G. M. 2011. Dietary Change and Evolution of Horses in North America. Science 331, 1178-1181.

Miller, R. 2012. Mapping the expansion of the Northwest Magdalenian. Quaternary International 273, 209-230.

Miras, Y. and Surmely, F., 2006. Environnement et peuplement de la moyenne montagne du Tardiglaciaire à nos jours. BOOK, Presses Univ. Franche-Comté.Vol. 799

Musil, R. 2000 Hunting in Central Europe at the End of the Last Glacial. Anthropologie et Préhistoire 111, 233-236.

De Nadaillac, A. 1887. Mœurs et monuments des peuples pré-historiques. Comptes-rendus des séances de l'Académie des Inscriptions et Belles-Lettres, Année 1887, 31, 42-49.

Naiman, R. J., Johnston, C.A. \& Kelly, J. C. 1988. Alteration of North American streams by beaver. Bioscience 38, 753-762.

Nitecki, M.H. \& Nitecki D.V. (Eds) 1987. Evolution of Human Hunting. Proceedings of the Field Museum of Natural History Ninth Annual Spring Systematics Symposium of the Evolution of Human Hunting, held May 10, 1986, in Chicago, Illinois. Plenum Press, New York Odling-Smee, J., Erwin, D.H., Palkovacs, E.P., Feldman, M.W. \& Laland, K.N. 2013. Niche construction theory: A practical guide for ecologists. The Quaterly Review of Biology 88, 328.

Odling-Smee, F.J., Laland, K.N. \& Feldman, M.W. 2003. Niche Construction.The Neglected Process in Evolution. Princeton University Press, Princeton. 
Osborn, H.F. 1915. Men of the Old Stone Age: Their Environment, Life and Art. Library of Alexandria, USA.

Osgood, C. 1940. Ingalik Material Culture. Yale University Publications in Anthropology No. 22.

Pacher, M. 2006. Large mammal remains from the Mladec ${ }^{2}$ Caves and their contribution to site formation processes. In Teschler-Nicola, Maria. Early Modern Humans at the Moravian Gate: The Mladec ${ }^{2}$ Caves and their Remains. Springer-Verlag, 99-148.

Pion, G., 2009. La fin du Paléolithique supérieur dans les alpes du nord françaises et le Jura méridional. Approches culturelles et environmentales., 255-270.

Pante, M.C., Blumenschine, R.J., Capaldo, S.D., \& Scott, R.S., 2012. Validation of bone surface modification models for inferring hominin and carnivore feeding interactions, with reapplication to FLK 22, Olduvai Gorge, Tanzania. Journal of Human Evolution 63, 395407.

Pastre, J. -F., Limondin-Lozouet, N., Leroyer, C, Ponel, P. \& Fontugne, M. 2003. River system evolution and environmental changes during the Lateglacial in the Paris Basin (France). Quaternary Science Reviews 22, 2177 - 2188.

Pêcheurs, A. D. E. S., Flandin, D. E. L. a B., Moncel, M., Daujeard, C., Cregut-bonnoure, É., Boulbes, N., Puaud, S., Debard, É., Bailon, S., Desclaux, E., Escude, É., Roger, T. and Dubar, M., 2010. Nouvelles données sur les occupations humaines du début du Pléistocène supérieur de la moyenne vallée du Rhône (France). Les sites de l'Abri des Pêcheurs, de la Baume Flandin, de l'Abri du Maras et de la Grotte du Figuier (Ardèche). Quaternaire, 21 (4), 385-411.

Petillon, J-M. 2008. What are these barbs for? Preliminary reflections on the function of the Upper Magdalenian barbed weapon tips / Des barbelures pour quoi faire? Reflexions preliminaires sur la fonction des pointes barbelees du Magdalenien superieur. Palethnologie 1, 66-97/69-102.

Peyrona, O., Be'geota T, C., Brewerb S.,. Heiric, O., Magnya, M., Milleta, L., Ruffaldia, P., Van Campod, E. and Yue, G. 2005. Late-Glacial climatic changes in Eastern France (Lake Lautrey) from pollen, lake-levels, and chironomids. Quaternary Research 64, 197- 211

Pfeiler, E. 1986. Towards and explanation of the developmental strategy in leptocephalous larvae of marine teleost fishes. Environmental Biol. Fish. 15, 3-13.

Piette, E. 1907. L'Art pendant l'âge du renne. Paris.

Pigaud, R. 2002. Le Cheval dans l'Art paléolithique : observé, disséqué... interprété. In Bodson, L. (Ed.) D'os, d'images et de mots. Contribution à la réflexion sur les sources de I'histoire des connaissances zoologiquies. Université de Liège, Liège, 3-34. 
Ponel, P. \& Coope, G. R. 1990. Lateglacial and eaerly Flandrian coleoptera from La Taphanel, Massif Central, France : Climatic and ecological implications. Journal of Quaternary Science 5, 235-249.

Power, R.C., Salazar-García, D.C., Straus, L.G., González Morales, M.R. \& Henry, A.G. 2015. Microremains from El Mirón Cave human dental calculus suggest a mixed plant-animal subsistence economy during the Magdalenian in Northern Iberia, Journal of Archaeological Science 60, 39-46.

Pozzi E. 2004. Les Magdaléniens. Art, civilisations, modes de vie, environnements. Grenoble, Millon.

Prosek, J. 2011. Eels: An Exploration from New Zealand to the Sargasso of the Worlds Most Mysterious Fish. Harper Collins, New York.

Radini, A., Buckley, S., Rosas, A., Estalrrich, A., de la Rasilla, M., Hardy. K. in press. Neanderthals and Trees: Non-edible conifer fibres found in Neanderthal dental calculus suggests extra-masticatory activity. Antiquity

Roach, N.T., Venkadesan, M., Rainbow, M.J. \& Lieberman, D.E. 2013. Elastic energy storage in the shoulder and the evolution of high-speed throwing in Homo. Nature 498, 483-487.

Roselló, E., Morales, A., 1995. Ictiofauna. In: Cacho, C., Fumanal, M.P., López, P., López, J.A., Pérez Ripoll, M., Martínez Valle, R., Uzquiano, P., Arnanz, A., Sánchez Marco, A., Sevilla, P., Morales, A., Roselló, E., Garralda, M.D., García-Carrillo, M. (Eds.), El Tossal de la Roca (Vall d'Alcalà, Alicante). Reconstruccio'n paleoambiental y cultural de la transicio'n del Tardiglaciar al Holoceno Inicial. Recerques del Museu d'Alcoi, IV, pp. 63-65.

Rhind, P. \& Jones, B. 2003. The vegetation history of Snowdonia since the Lateglacial Period. Field Studies 10, 539 - 552

Rice, P.C. \& Paterson, A.L. 1996. Bone art in the Upper Palaeolithic: regional, temporal, and art classcomparisons. Cross-Cultural Research 30, 211-42

Righton, D. \& Roberts, M. 2014. Eels and people in the United Kingdom. In K. Tsukamoto \& M. Kuroko (EDS.) Eels and Humans, Springer, Japan, 1-12.

Roberts, M.B. \& Parfitt, S.A. 1999. Boxgrove. A Middle Pleistocene hominid site at Eartham Quarry, Boxgrove, West Sussex. London: English Heritage Archaeological Report 17. 456pp.

Román, D. \& Villaverde, V. 2012. The Magdalenian harpoons from the Iberian Mediterranean, base don pieces from Cova de les Cendres (Teulada-Moraire, Valencia region). Quaternary International 272-273, 33-41. 
Salazar-García, D.C. Power, R.C. Sanchis Serra, A. Walker, M.J. \& Henry, A.G. 2013. Neanderthal diets in central and southeastern Mediterranean Iberia. Quaternary International 318, 3-18.

Schmidt, E. J. 1922. The breeding places of the eel. Phil. Trans. Roy. Soc. 211, 179-208.

Shillito, L.M. 2013. Grains of truth or transparent blindfolds? A review of current debates in archaeological phytolith analysis. Vegetation History and Archaebotany 22, 7182.

Simões de Abreu \& Bednarik, R. G. 2000. Fariseu rock art not archaeologically dated. Rock Art Research 17, 2000, 65-68.

Sinha, V.R. \& Jones, J. W. 1975. The European freshwater eel. Liverpool University Press. $146 p$.

Smart, D. J.Q. 2003. Later Mesolithic Fishing Strategies and Practices in Denmark. BAR International Series 1119

Smith, B.D. 2007. Nice construction and the behavioural context of plant and animal domestication. Evolutionary Anthropology 16, 188-199.

Soffer O., Adovasio, J.M. \& Hyland, D.C. 2000a. The 'Venus' figurines, textile, basketry, gender, and status in the Upper Palaeolithic. Current Anthropology 41, 4: 511-37.

Soffer, O., Adovasio, J.M., Illingworth, J.S., Amirkhanov, H.A., Prasvlov, N.D., \& Street, M., 2000b. Palaeolithic Perishables made Permanent. Antiquity 74, 812-821.

Stapert, D. \& Street, M. 1997. High resolution or optimum resolution? Spatial analysis of the Federmesser site at Andernach, Germany. World Archaeology 29, 172-194.

Stachurska, A.M. 1999. Inheritance of primitive markings in horses. J. Anim. Breed. Genet. 116: 29-38.

Stevens, R. E., O'Connell, T. C., Hedges, R. E. M. and Street, M., 2009. Radiocarbon and stable isotope investigations at the Central Rhineland sites of Gönnersdorf and Andernach-Martinsberg, Germany. Journal of Human Evolution, 57 (2), 131-148.

Stiner, M.C. 2002. Carnivory, Coevolution, and the Geographic Spread of the Genus Homo. Journal of Archaeological Research 10, 1-63.

Stiner, M. Barkai, R. \& Gopher, A. 2009. Cooperative hunting and meat sharing $400-200$ kya at Qesem Cave, Israel. PNAS 106 (32), 13207-13212.

Straus, G., 1988. L'abri Dufaure et la Falaise du Pastou dans le système adaptatif régional des Pyrénées au Magdalénien. Colloque de Chancelade, 335-343.

Street, M. and Baales, M., 1997. Les groupes à Federmesser de l'Allerød en Rhénanie centrale 
(Allemagne). Bulletin de La Société Préhistorique Française, 94 (3), 373-386.

Street, M., Gelhausen, F., Grimm, S., Moseler, F., Niven, L., Sensburg, M., Turner, E., Wenzel, S. and Jöris, O., 2006. L'occupation du bassin de Neuwied (Rhénanie centrale, Allemagne) par les Magdaléniens et les groupes à Federmesser (aziliens). Bulletin de La Société Préhistorique Française, 103 (4), 753-780.

Svoboda, J. 2001. Mladec and other caves in the Middle Danube region: early modern humans, late Neandertals, and projectiles. Les premiers homes modernes de la Peninsule Iberique, 45-60.

Sato, M. 1917. Blood serum of the eel. Nippon Biseibutsugakukai Zasshi 5, 473-.

Schwartz, J. \& Tattersall, I. 2006. Foreward, in M. Teschler-Nicola (ed.), Early Modern Humans at the Moravian Gate: Mladec Caves and their Remains, XI-XIII. Vienna/New York: Springer.

Shennan, S. 2001 Demography and cultural innovation: A model and its implications for the emergence of modern human culture. Cambridge Archaeological Journal 11, 5-16

Sieveking, A. 1987. A Catalogue of Palaeolithic art in the British Museum. London, British Museum Publications Ltd.

Sistiaga, A., Mallol C., Galván, B., \& Summons, R.E. 2014. The Neanderthal Meal: A New Perspective Using Faecal Biomarkers. PLoS ONE 9, e101045.

Sommer, R. \& Beneck, N. 2004. Late- and Post-Glacial history of mustelids. Mammal Review 34, 249-284.

Speth, 1991. Nutritional constraints and Lateglacial adaptive transformations: the importance of non-protein energy sources. In Barton, N., Roberts, A.J. \& Roe, D.A. (Eds.) The Lateglacial in north-west Europe: human adaptation and environmental change at the end of the Pleistocene. Council for British Archaeology Research Report 77, 169-178.

Stevens R.E., O'Connell T., Hedges,R.E.M. \& Street, M. 2009. Radiocarbon and stable isotope investigations at the Central Rhineland sites of Gönnersdorf and AndernachMartinsberg, Germany. Journal of Human Evolution 57, 131-148

Tesch, F.W. 2003. The Eel. Fifth Edition, Blackwell, Oxford.

Thonicke, K., I. C. Prentice, \& Hewitt, C. 2005. Modeling glacial-interglacial changes in global fire regimes and trace gas emissions, Global Biogeochem. Cycles 19, GB3008, 1-10.

Turner, E. 2005. Results of a recent analysis of horse remains dating to the Magdalenian period at Solutre, France. In Mashkour, M (ed.). Equids in Time and Space. Oxbow Books, Oxford 70-89. 
Turner, E. 2006. Results of a recent analysis of horse remains dating to the Magdalenian period at Solutré, France. In Mashkour, M.Z. (Eds.) Equids in Time and Space: Papers in Honour of Véra Eisenmann. Oxbow Books, Oxford, 70-91.

Tsukamoto, K. \& Kuroki, M. 2014. Eels and Humans. Springer, Japan.

Tyldesley, J.A. \& Bahn, P.G. 1983. Use of plants in the European Palaeolithic: A review of the evidence. Quaternary Science Reviews 2, 53-81.

Urban, B. \& Bigga, G., 2015. Environmental reconstruction and biostratigraphy of late Middle Pleistocene lakeshore deposits at Schöningen. Journal of Human Evolution 89, 57-70.

van Andel, T.H. \& W.D. Davies (Eds.). 2003. Neanderthals and Modern Humans in the European Landscape of the Last Glaciation - Archaeological Results of the Stage 3 Project. The McDonald Institute for Archaeological Research: Cambridge.

van Neer, W., Wouters, W. \& Germonpre, M. 2007. Fish remains from three Upper Palaeolithic cave deposits in southern Belgium. Anthropologica et Praehistorica 118, 5-22.

Vøllestad, L. A. 1992. Geographic variation in age and length at metamorphosis of maturing European eel: environmental effects and phenotypic plasticity. Journal of Animal Ecology 61, 41-48.

Walker, M.J.C. et al., 2009. Formal definition and dating of the GSSP (Global Stratotype Section and Point) for the base of the Holocene using the Greenland NGRIP ice core, and selected auxiliary records. Journal of Quaternary Science 24, 3-17.

Walker, M.J.C. et al. 2012. Formal subdivision of the Holocene Series/Epoch: a Discussion Paper by a Working Group of INTIMATE (Integration of ice-core, marine and terrestrial records) and the Subcommission on Quaternary Stratigraphy (International Commission on Stratigraphy). Journal of Quaternary Science 24, 3-17.

Westbrook, C.J., Cooper, D.J. \& Baker, B.W. 2011. Beaver assisted river valley formation. River Research and Applications 27, 247-256.

Wheeler, A. 1969. Fishes of the British Isles and North West Europe. Macmillan, London. Wojtal, P., Wilczyński, J., Nadachowski, A. and Münzel, S. C., 2015. Gravettian hunting and exploitation of bears in Central Europe. Quaternary International, 359 , 58-71.

Xiang M, Alfvén G, Blennow M, Trygg M, \& Zetterström R. 2000. Long-chain polyunsaturated fatty acids in human milk and brain growth during early infancy. Acta Paediatrica 89, $142-$ 147.

Yoshida, M., Sone, S. \& Shiomi, K. 2008. Purification and characterization of a proteinaceous toxin from the serum of Japanese eel Anguilla japonica. Protein Journal 27, 450-454. 
Zhilin, M.G. 2014. Early Mesolithic hunting and fishing in Central Russia on Wetland Sites. Journal of Wetland Archaeology 14, 91-105.

Zubrow, E. 2010. Archaeology of Equality: Magdalenian Economy. In Zubrow, E.B.W., Audouze, F. \& Enloe, J.G. (Eds.) The Magdalenian Household Unraveling Domesticity. SUNY Series, The Institute for European and Mediterranean Archaeology Distinguished Monograph Series, 109-130.

Zvelebil, M. 2008. Innovating Hunter-Gatherers: The Mesolithic in the Baltic. In Bailey (Ed.) Mesolithic Europe. Cambridge University Press, Cambridge, 18-59. 


\section{Figures Caption}

Fig. 1. Magdalenian Europe with ecological, palaeontological and Magdalenian art sites mentioned in the text. Stars: sites with art reproduced in this paper, solid circles other Magdalenian sites mentioned in the text.

Fig. 2 A poke pole being used to flush eels out for filming. Photo courtesy of the Monkeyface News.

Fig. 3 A scene of horse-head eeling from 1979 adaptation of The Tin Drum by Gunter Grass directed by Volker Schlöndorff and produced by Jadran Films. Reproduction by permission of Jadran Films, Croatia.

Fig. 4. A Maori eel-weir on the outlet stream of Horowhenua lake New Zealand (above) and eel killing baton (patu tuna) and eel spears (matarau) (below). By permission from Museum of New Zealand Collections. Weir photographer Leslie Adkin 1925, gift of the G.L. Adkin family estate 1964.

Fig. 5. "Snake or eel, man and two horse heads" from Abri La Madelaine redrawn from Marshack (1972). Redrawn and adapted from original (C) MNP Les Eyzies - Dist.RMN - cliché Ph. Jugie.

Fig. 6. Engraving on a bâton de commandement from Grotte ds Montgaudiet, drawn by Albert de Nadaillac, Comptes-rendus des séances de l'Académie des Inscriptions et BellesLettres, Année 1887, ,Volume 31, Numéro 1, pp. 42-49 and reproduced courtesy of creative commons.

Fig. 7. "horses head with herbage" from Grotte du Mas d'Azil. Adapted from Tyldesley and Bahn (1983). This image was published in Quaternary Science Reviews, Vol. 2 number 1, Tyldesley, J.A. \& Bahn, P.G. 1983, Use of plants in the European Palaeolithic: A review of the evidence, Page Nos 53-81, Copyright Elsevier (1983).

Fig. 8. Three panels from Lortet. Magdalenian. From Antropomorfos en la Cueva de los Casaresal Website, reproduced by permission through Creative Commons. (http://quintadimension.blogcindario.com/2008/09/00019-antropomorfos-en-la-cueva-delos-casares.html

Fig. 9. engraved bone of an anthropomorph entitled "The sorcerer of La Madeleine" from Abri La Madelaine reproduced by oermission of the Musée Les-Eyzies-de-Tayac . (C MNP Les Eyzies - Dist.RMN - cliché Ph. Jugie.

Fig. 10. Schematic representation of ecological relationships between humans, beaver, eels and horses in the European Late Upper Palaeolithic. 


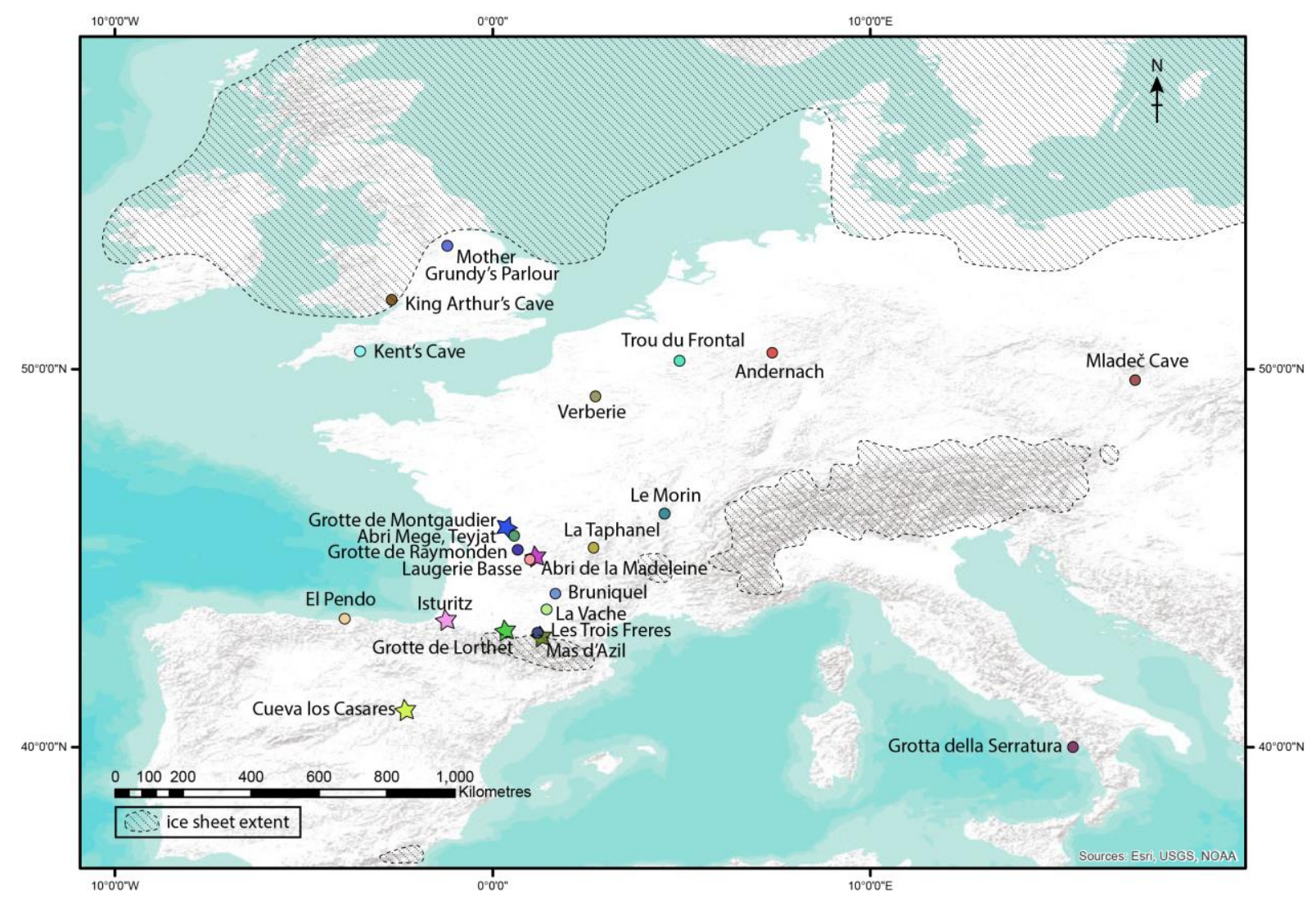

Fig. 1

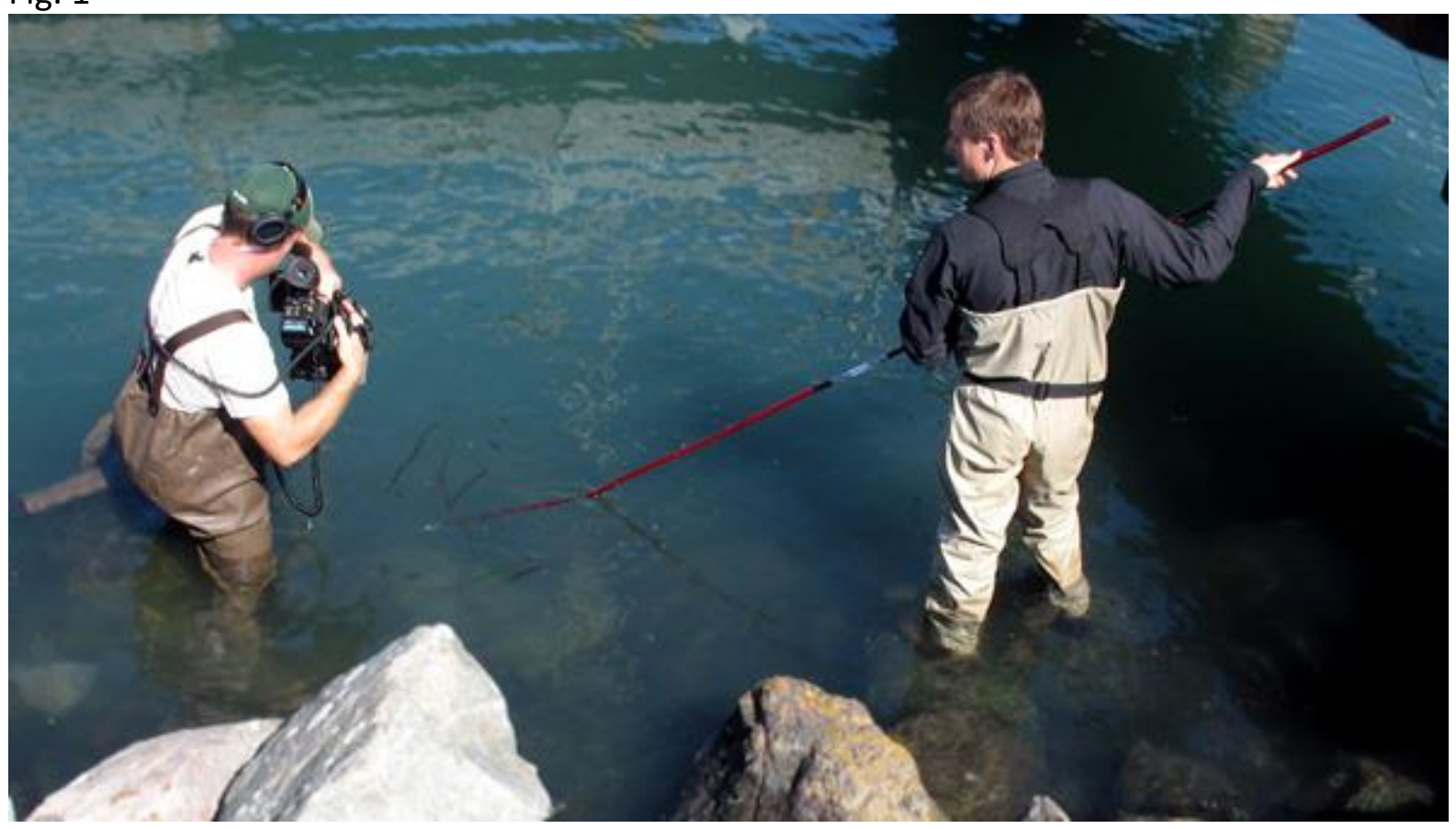

Fig. 2 


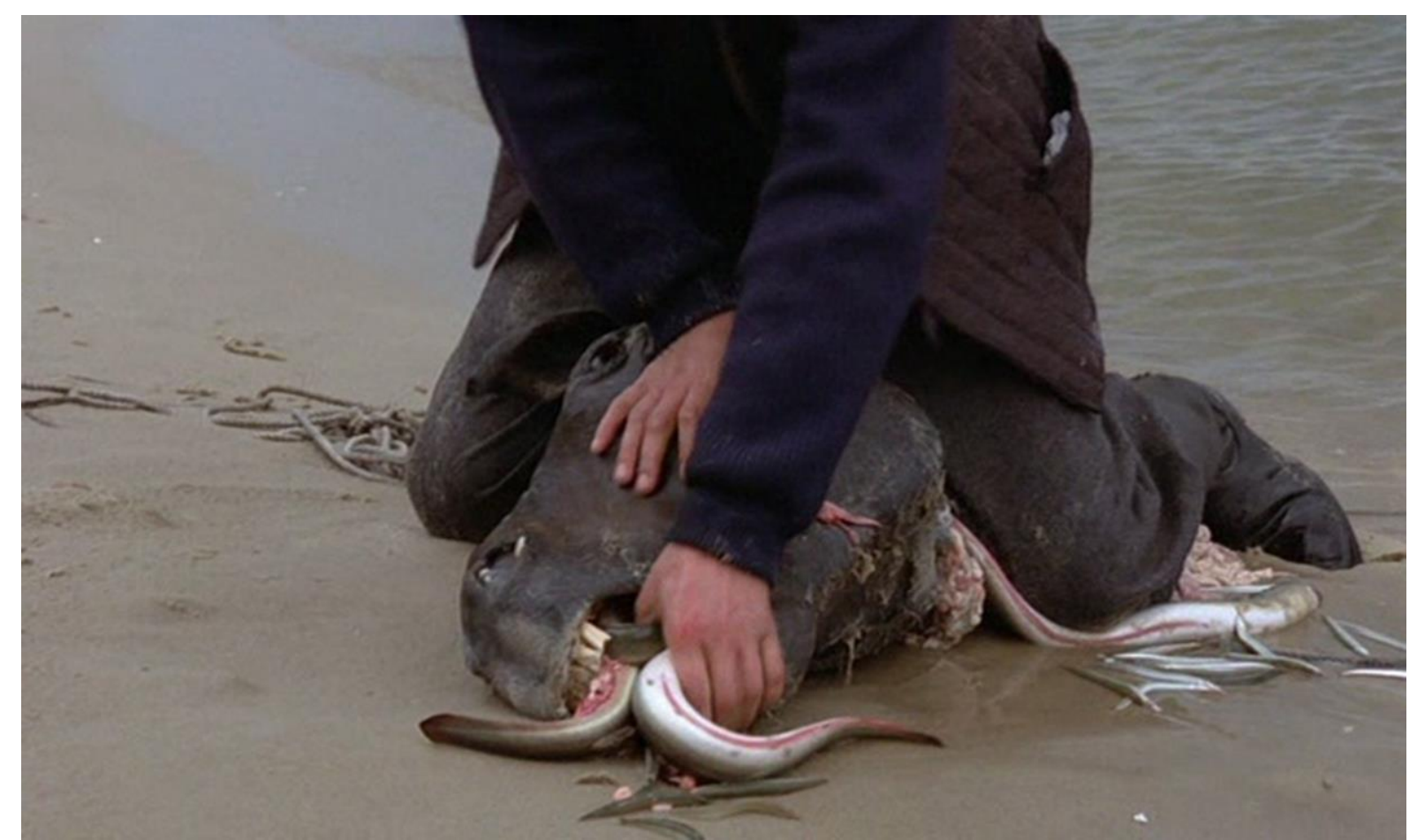

Fig. 3 


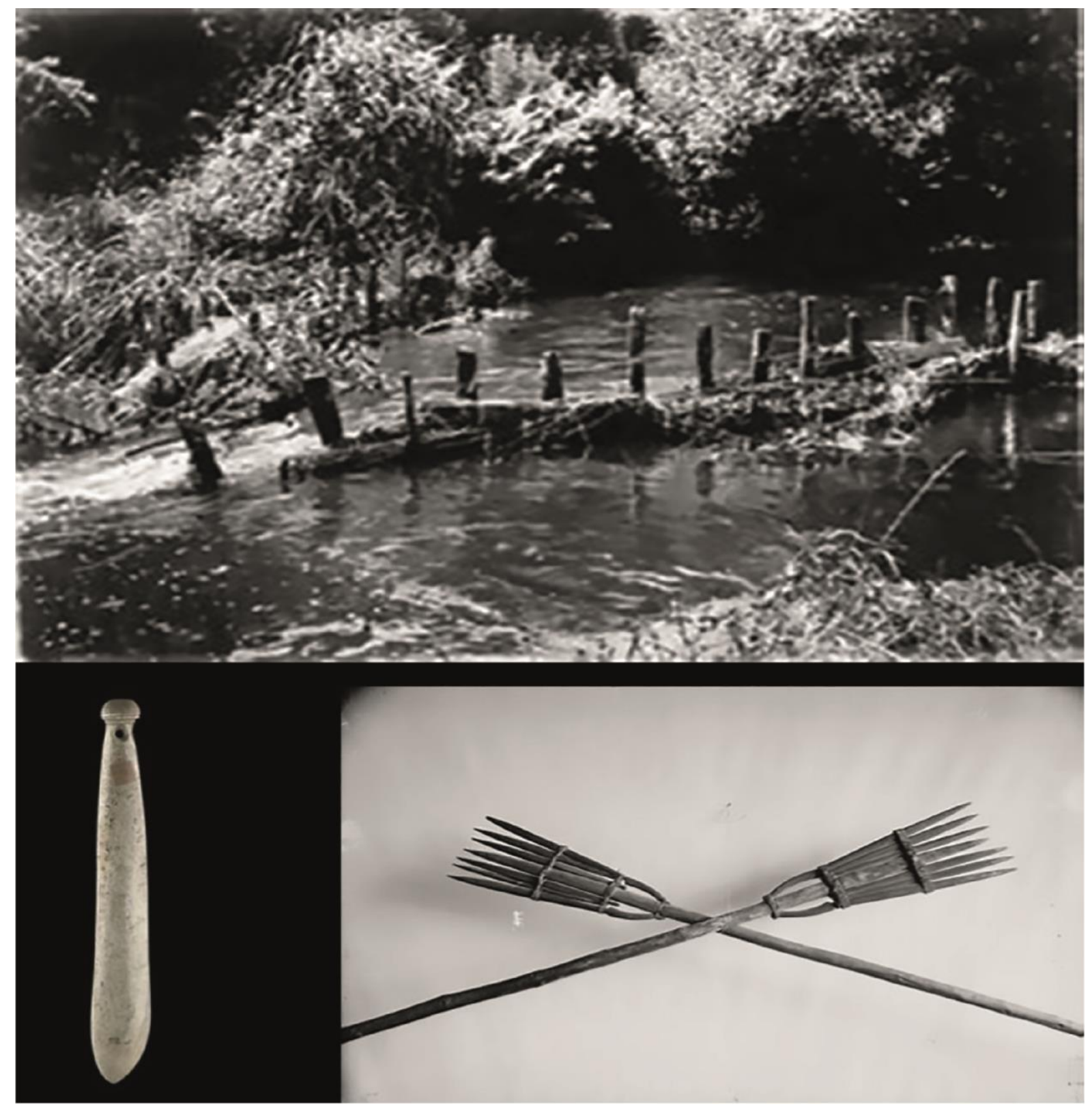

Fig. 4 


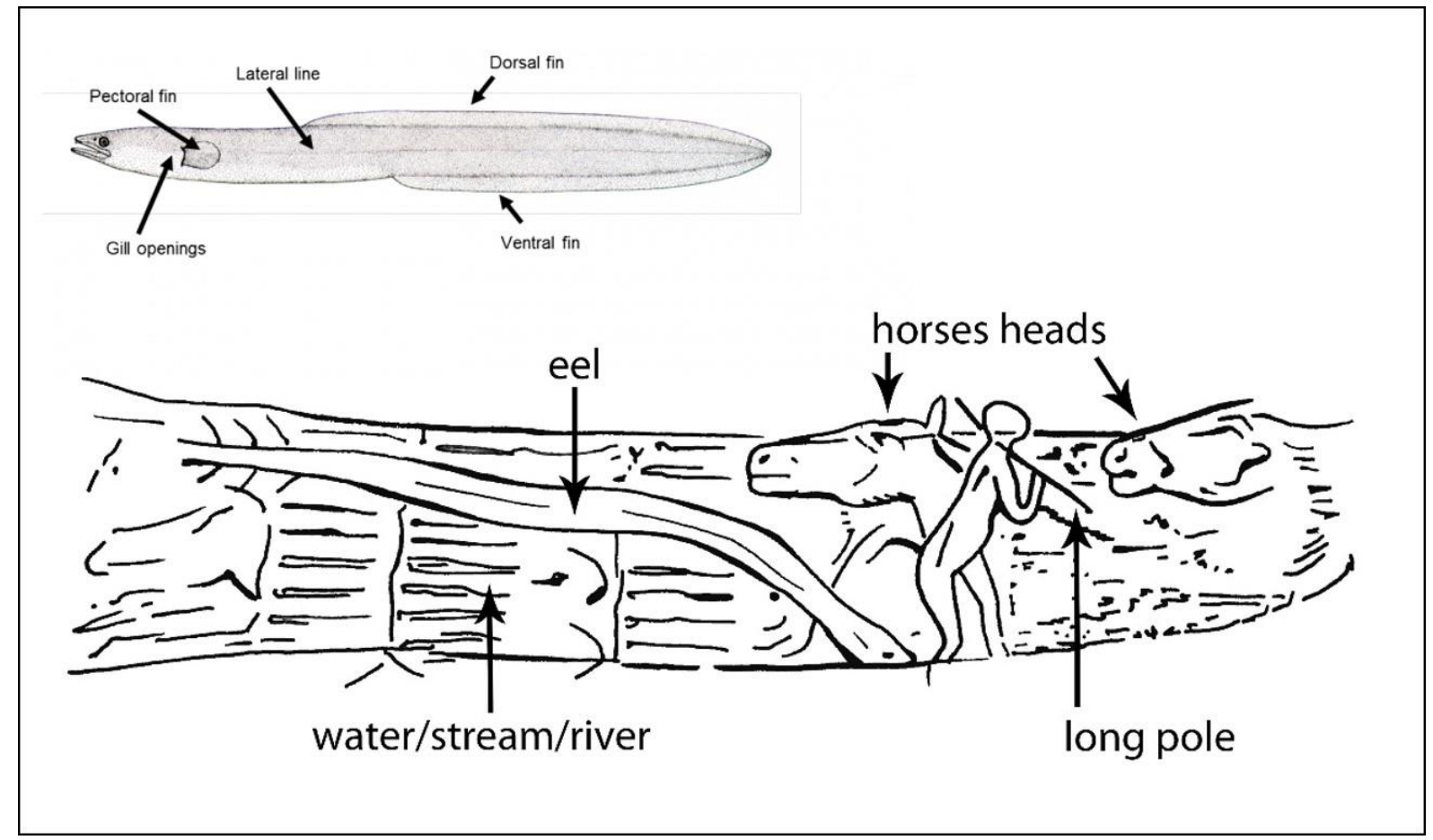

Fig. 5
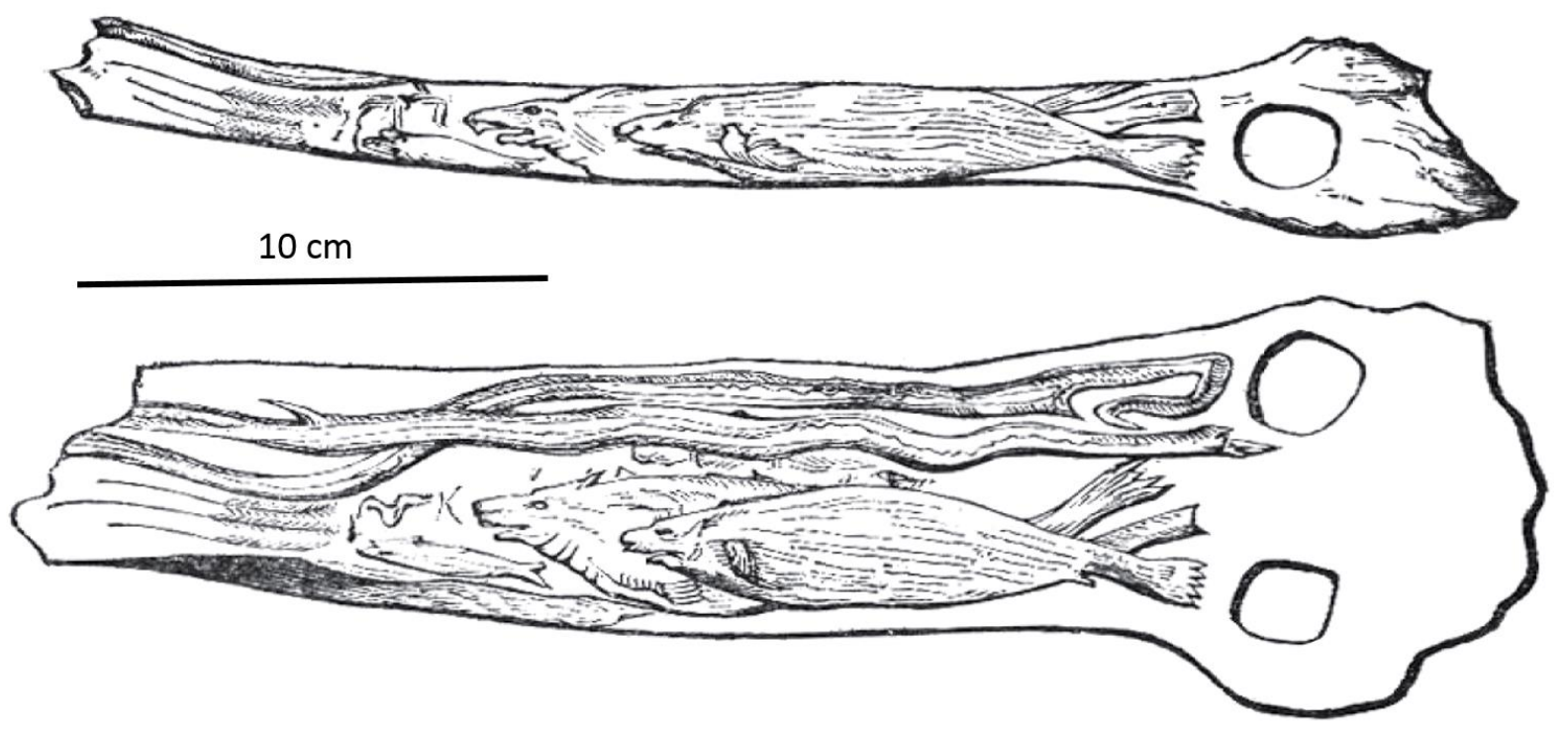

Fig. 6 


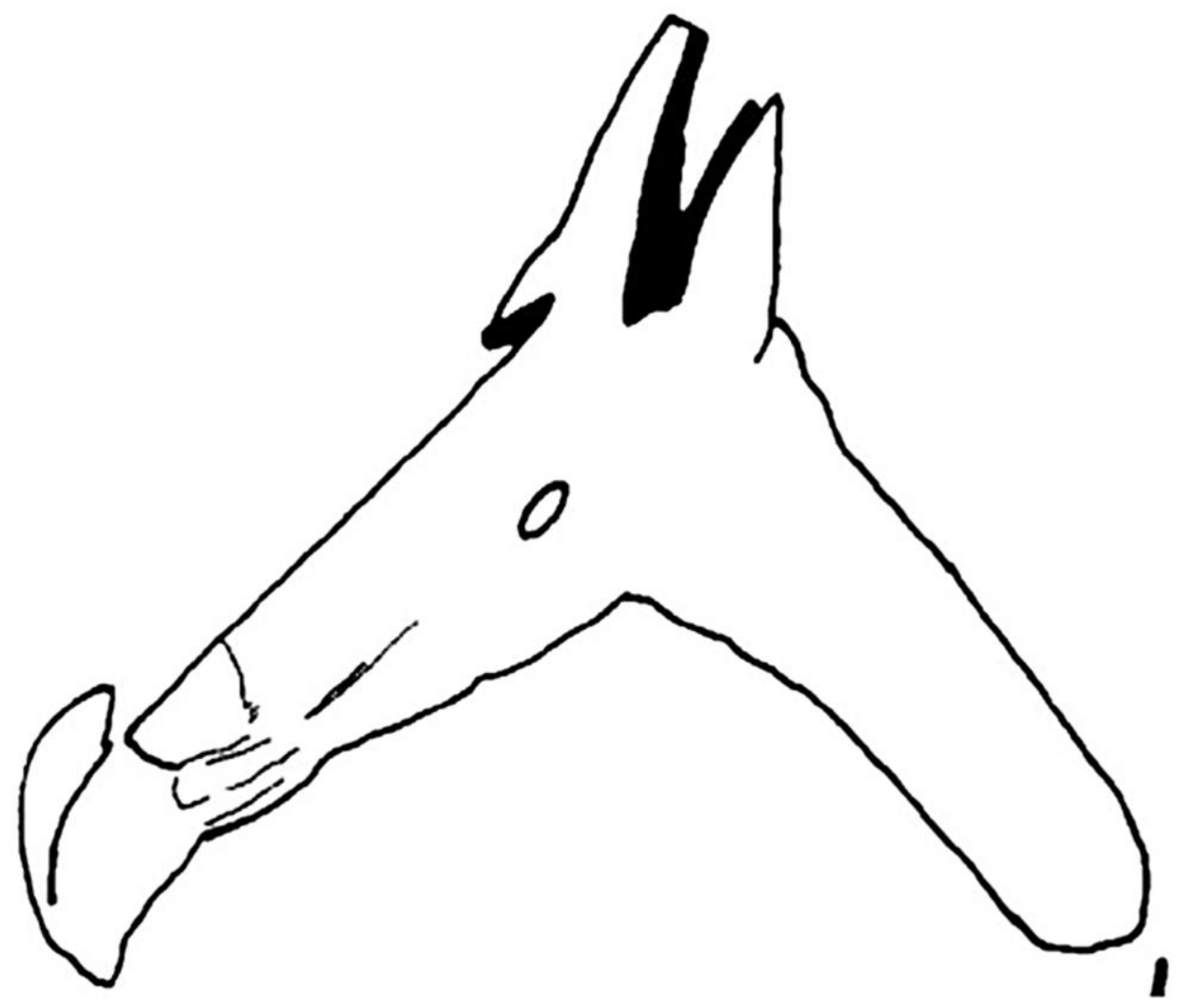

Fig. 7
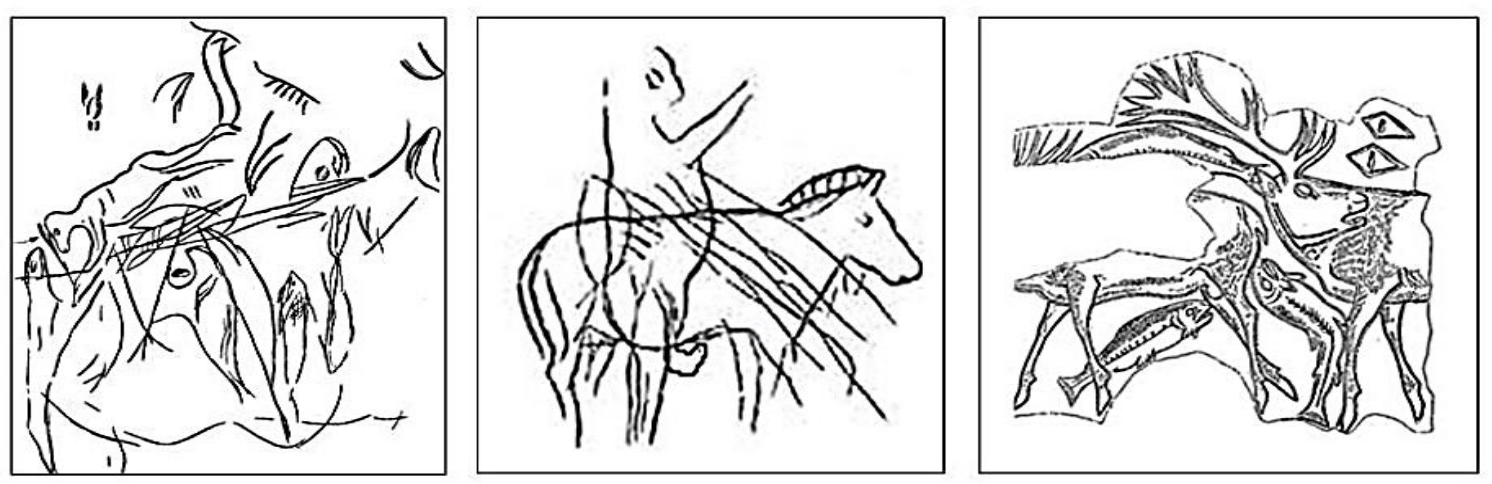

Fig. 8 


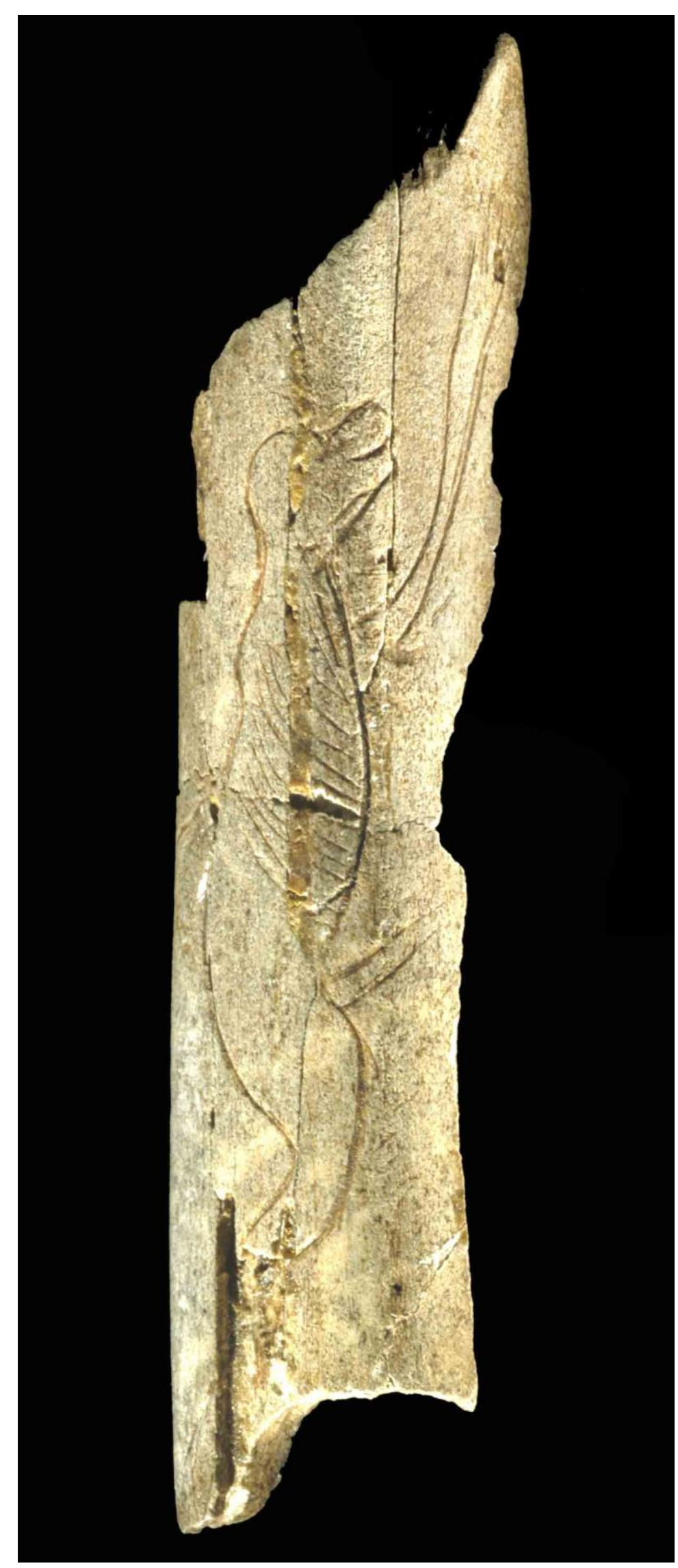

Fig. 9 


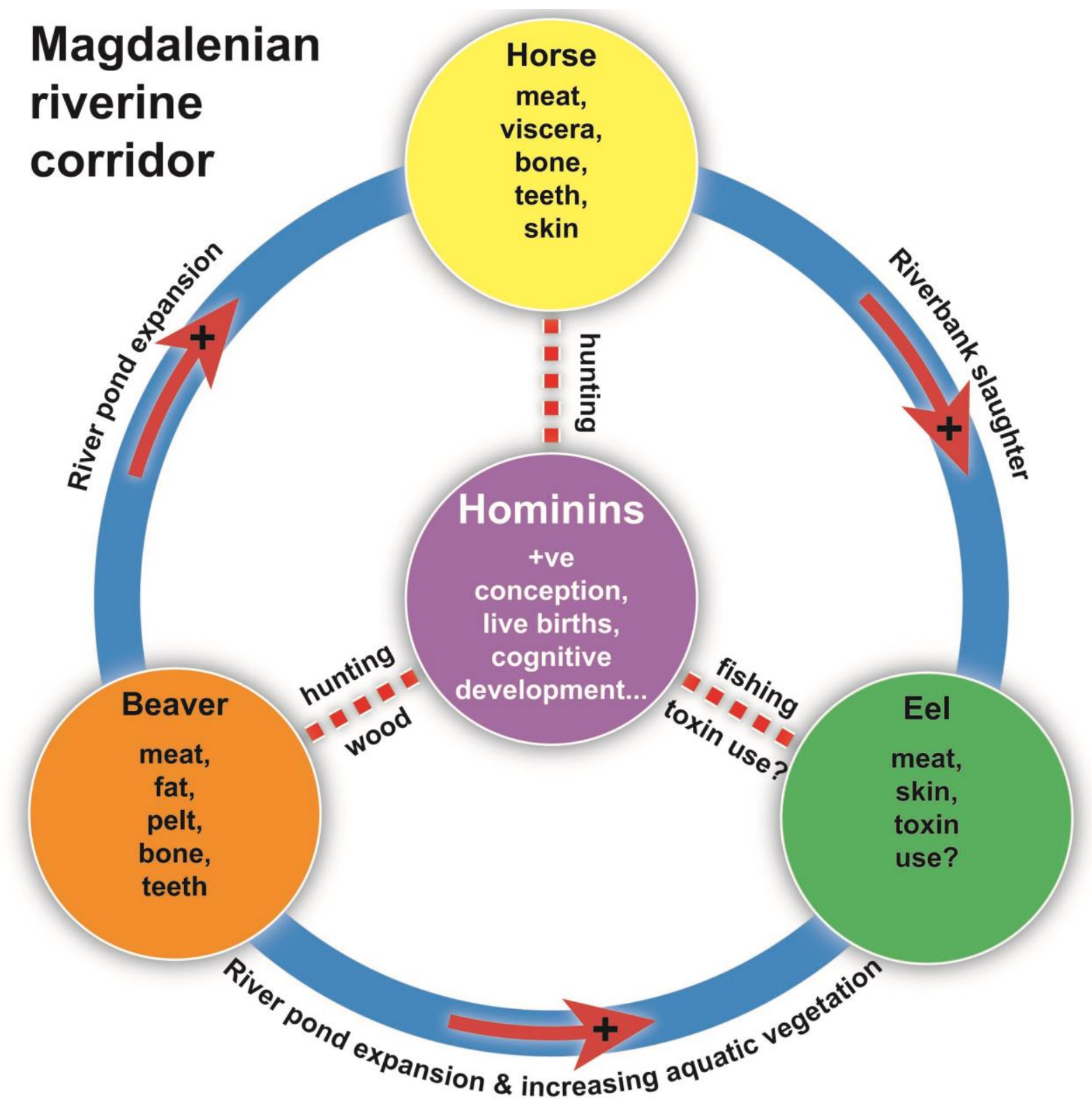

Fig. 10 